\title{
Roman Mosaics of Antequera. An Overview
}

\section{Antequera'nın Roma Mozaikleri. Genel Bir Bakış}

\author{
Sebastián VARGAS-VÁZQUEZ - Manuel ROMERO PÉREZ*
}

(Received 02 March 2021, accepted after revision 26 August 2021)

\begin{abstract}
The present-day city of Antequera, in the province of Malaga, Spain, dominates an extensive territory encompassing numerous archaeological sites from different eras. The urban centres of Singilia Barba, Anticaria and Aratispi, belong to the Roman period, now only offering us two mosaics, and a good number of rural properties, from which most of the set of Antequera mosaics come.

Within the Antequeran mosaic repertoire, the geometric mosaic occupies a special place, with specimens of great beauty and excellent design, for example those in the majestic Roman villa of La Estación. From a figurative point of view, Antequera has beautiful specimens, such as the Oceanus mosaic of the baths of Santa Maria and that of the Erotes and Priapus figures of the Roman villae of La Estación and Bobadilla, respectively. Particularly, the Roman villa of Caserio Silverio has a heritage consisting of a large number of figurative representations, highlighting the imposing, although poorly preserved, pavement of the triclinium. This mosaic must have contained a scene related to the mythology of water, of which singular fragments are preserved, such as the representation of the Tiber River and some epigraphic verses extracted from book IV of Vergil's Georgics.
\end{abstract}

Keywords: Baetica, Roman villa, Roman mosaic, Oceanus, Priapus, Vergil’s Georgics.

$\ddot{\mathrm{O} z}$

Íspanya'nın Malaga eyaletinde bulunan günümüz Antequera şehri, farklı dönemlerden çok sayıda arkeolojik alanı kapsayan geniş bir bölgeye hâkimdir. Singilia Barba, Anticaria ve Aratispi'nin kent merkezleri Roma Dönemi'ne aittir ve şimdi bize yalnızca iki mozaik ve Antequera mozaiklerinin çoğunun geldiği çok sayıda kirsal mülk sunmaktadir.

Antequeran mozaik repertuvarında, örneğin La Estación'un görkemli Roma villasında bulunanlar gibi, harika güzellik ve mükemmel tasarım örnekleri ile geometrik mozaik özel bir yere sahiptir. Figüratif bir bakıs açısından, Antequera, Santa María hamamlarının Oceanus mozaiği ve sırasıyla La Estación ve Bobadilla'nın Roma villalarının Eroslar ve Priapus figürleri gibi güzel örneklere sahiptir. Özellikle, Caserio Silverio'nun Roma villası, çok sayıda figüratif temsilden oluşan bir mirasa sahiptir ve tricliniumun kötü korunmuş olmasına rağmen heybetli döşemesini vurgulamaktadır. Bu mozaik, Tiber Nehri'nin temsili ve Vergilius'un Georgics'in IV. kitabından alınan bazı epigrafik dizeler gibi tekil parçalarının korunduğu su mitolojisiyle ilgili bir sahne içeriyor olmalıdır.

Anahtar Kelimeler: Baetica, Roma villası, Roma mozaiği, Oceanus, Priapus, Vergilius'un Georgics'i.

\footnotetext{
" Sebastián Vargas-Vázquez, University of Seville, Department of Prehistory and Archaeology, Seville, Spain. (D) https://orcid.org/0000-0002-6015412X. E-mail: svargas2@us.es

Manuel Romero Pérez, Municipal archaeologist of Antequera, Antequera Municipality, Málaga, Spain. (DD) https://orcid.org/0000-0002-7923-2079. E-mail: arqueologo@antequera.es

Work funded by VI Plan Propio de Investigación y Transferencia de la Universidad de Sevilla (VI PPIT-US).

This work is part of the $\mathrm{R}+\mathrm{D}+\mathrm{i}$ Project "Vivere in urbe. Arquitectura residencial y espacio urbano en Corduba, Ategua e Ituci. Investigación y socialización" (PID2019-105376GB-C43), granted by the Spanish Ministry of Science and Innovation, whose principal investigators are Ángel Ventura Villanueva and Sebastián Vargas-Vázquez.

The authors would like to thank Maja Kramer and Pedro Albuquerque for the care taken in reviewing the English version of this text.
} 
Antequera is situated in the provincia de Málaga (Southern Spain), in the ancient and rich territory of Conventus Astigitanus within the territorial limits of the ancient Roman Baetica. Part of this province coincide with the present-day Andaluzia (Fig. 1). Within its municipal boundary, it encompasses the former territories dependent on Anticaria, Singilia Barba and Aratispi. Next to these cities, a large number of Roman villae structured and gave cohesion to their vast and extensive territory, revealing, once again, the richness of the Baetic countryside, in which one of their key products, olive oil, acquired a main role. Up to a total of 203 Roman villae and / or rural structures have been documented in the Antequeran countryside, and olive oil production has been stated in 41 of them; among these, 27 belong to the ager anticariensis and singiliensi. Olive oil production is also documented at other sites in the surrounding area, now related to the Iberian Roman city of Aratispi and of the Laguna de Fuente de Piedra (Romero 2011-2012: 381-399) ${ }^{1}$.

The Roman remains documented today in Antequera are multiple and varied. Among them the rich mosaic heritage stands out, originating from the previously mentioned luxurious villae. Although to a lesser extent, the Roman city of Anticaria has also contributed to this heritage, showing that not only in urban areas but also in the countryside was mosaic one of the preferred types of pavement. In the case of the three cities documented today in the territory of Antequera, it has only been possible to document mosaic pavements in the old city of Anticaria, located under the current city of Antequera (Fig. 1). In the city of Singilia Barba, on the other hand, despite the monumentality manifested by its archaeological remains, the total absence of mosaics, so far, is significantly surprising.

In the case of the rural environment, the presence of mosaics is revealing, given that some of its Roman villae offer a rich and varied pavement catalogue.

In total, mosaics have been documented in the Antequeran villae of Bobadilla, Carnicería de los Moros, La Estación and Caserío Silverio (Fig. 1), while in other rural properties the presence of this type of pavement can only be suggested with the help of one's imagination. Such is the case of the villae of Huerta del Ciprés (Cisneros et al. 2016: 453, 456), where the pars urbana is still to be excavated, and La Quinta, where remains of a mosaic were documented nearby.
Figure 1

Antequera in Spain's Map and location of the Antequeran archaeological sites cited in this paper on relief Map Iberpix IGN. 2021

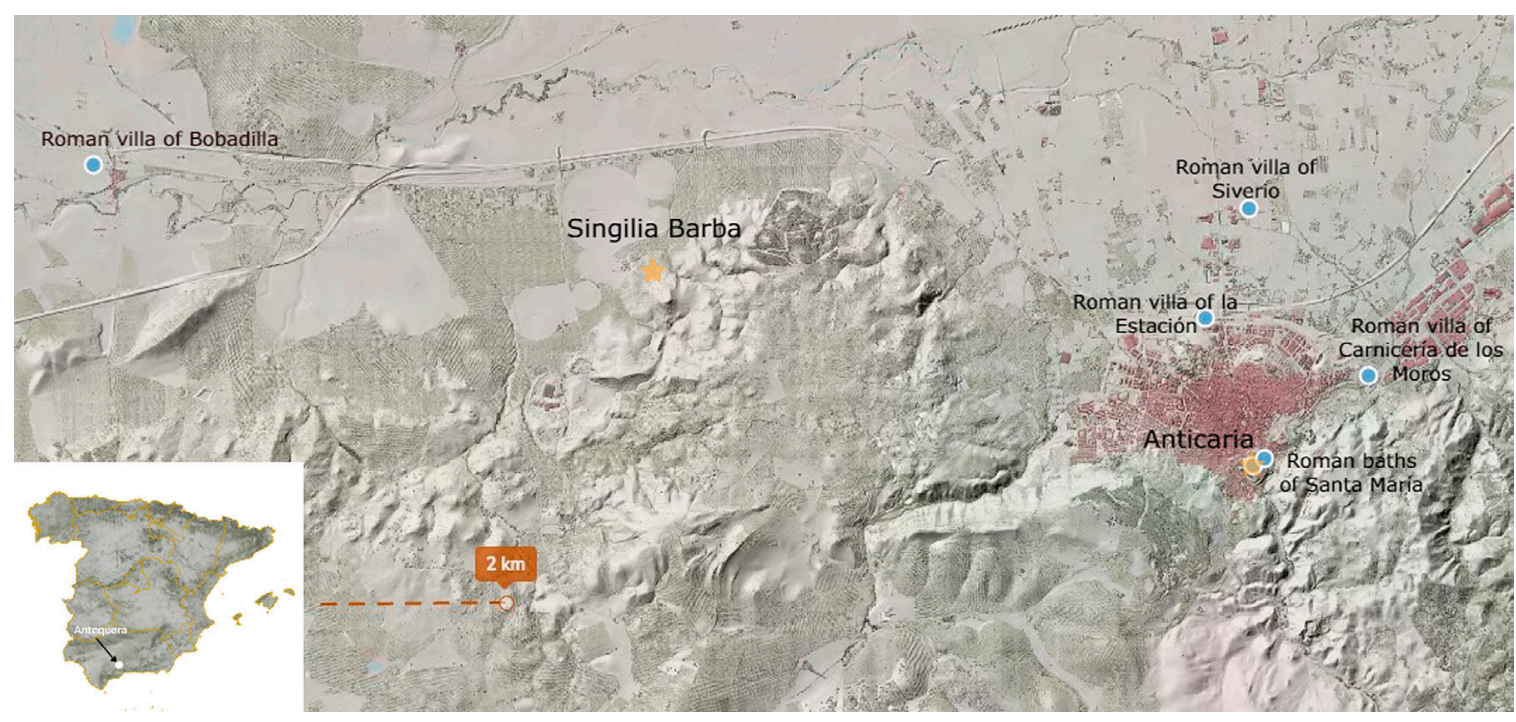

1 For a more accurate knowledge of the Roman villae of Antequera, particularly their definition, location, production features, etc., see Romero 1998: 115-141; 2001: 278-279; 2011: 53-80. 


\section{Documented Mosaics in Urban Settings}

\section{Roman baths of Santa María}

The Roman baths of Santa María, located next to the current Collegiate Church of Santa María, belong to the city of Anticaria (Atencia et al. 1990: 220-226; Atencia 1991: 157-159).

This is a spectacular public bath complex where two mosaics dated to the first half of the third century are preserved (Fig. 2). One of them paves a large area interpreted as the apodyterium of the bath, and is characterized by its wide field of ceramic tesserae (Fig. 3). In this mosaic, two small spaces are reserved for emblems or symbols that contain representations of a goblet crater (Fig. 4) and a dolphin with a trident or pitchfork (Fig. 5), which could allude to the Roman god Neptune, although not necessarily. The particularity of mosaics that have a wide field with abundant ceramic tesserae, opus figlinum, is very significant in Roman Baetica. One of our team members is currently studying and cataloguing them. They are also documented in other Antequeran villae, such as in Caserío Silverio, and in other areas of Baetica like Écija and Sevilla (Vargas-Vázquez 2016: 304-305).

Figure 2

Orthophoto of the baths of Santa María de Antequera. Courtesy of Oficina Arqueológica de Antequera.

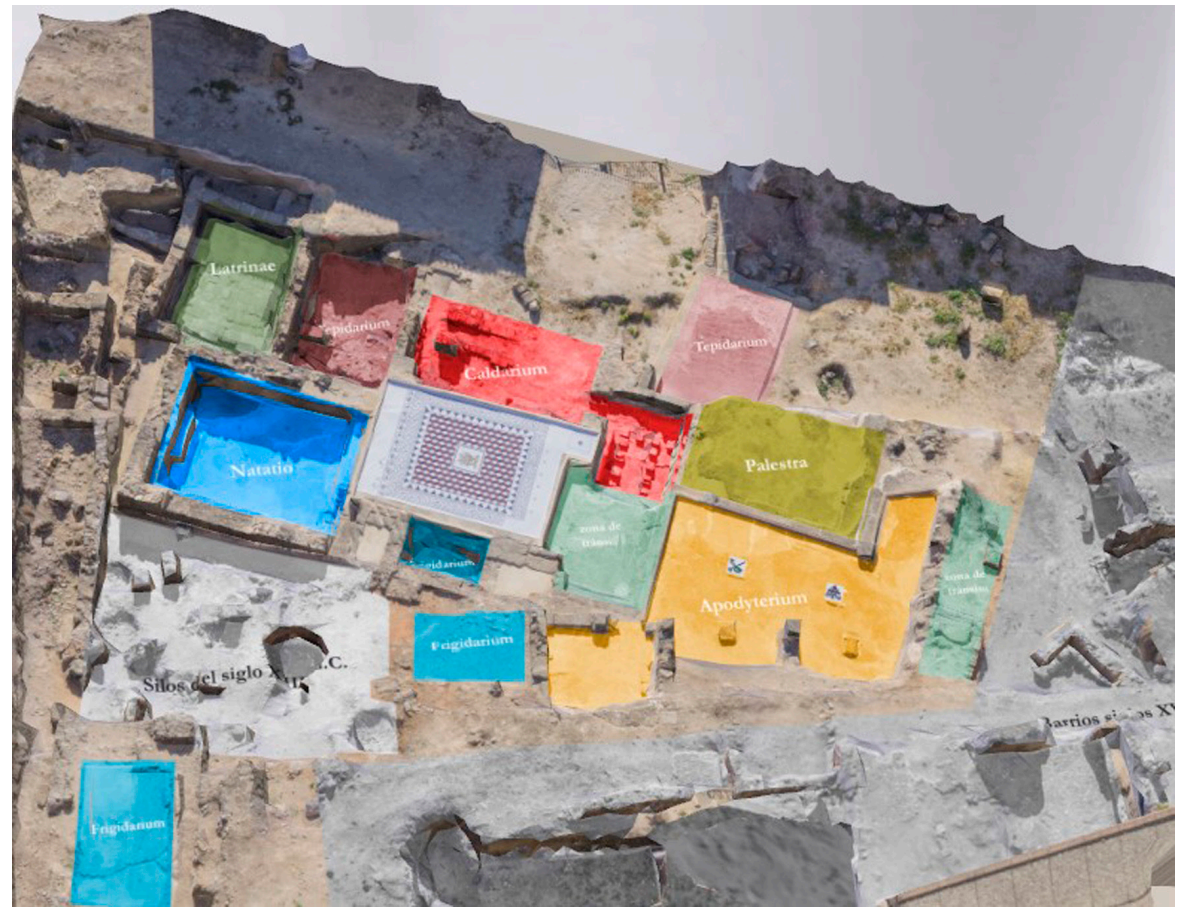

Figure 3

Baths of Santa María de Antequera: Apodoteryum's mosaic. Courtesy of Oficina Arqueológica de Antequera.

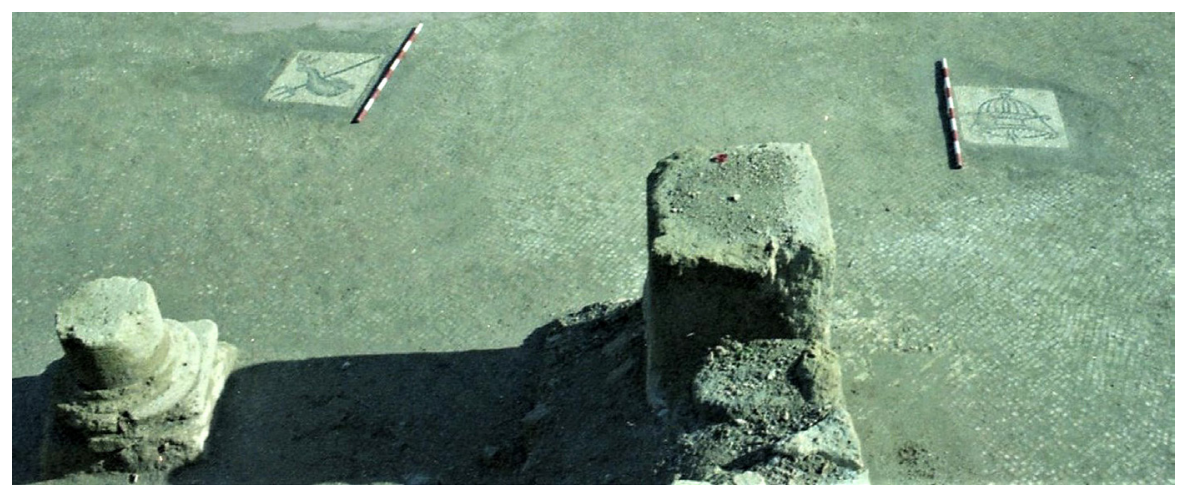



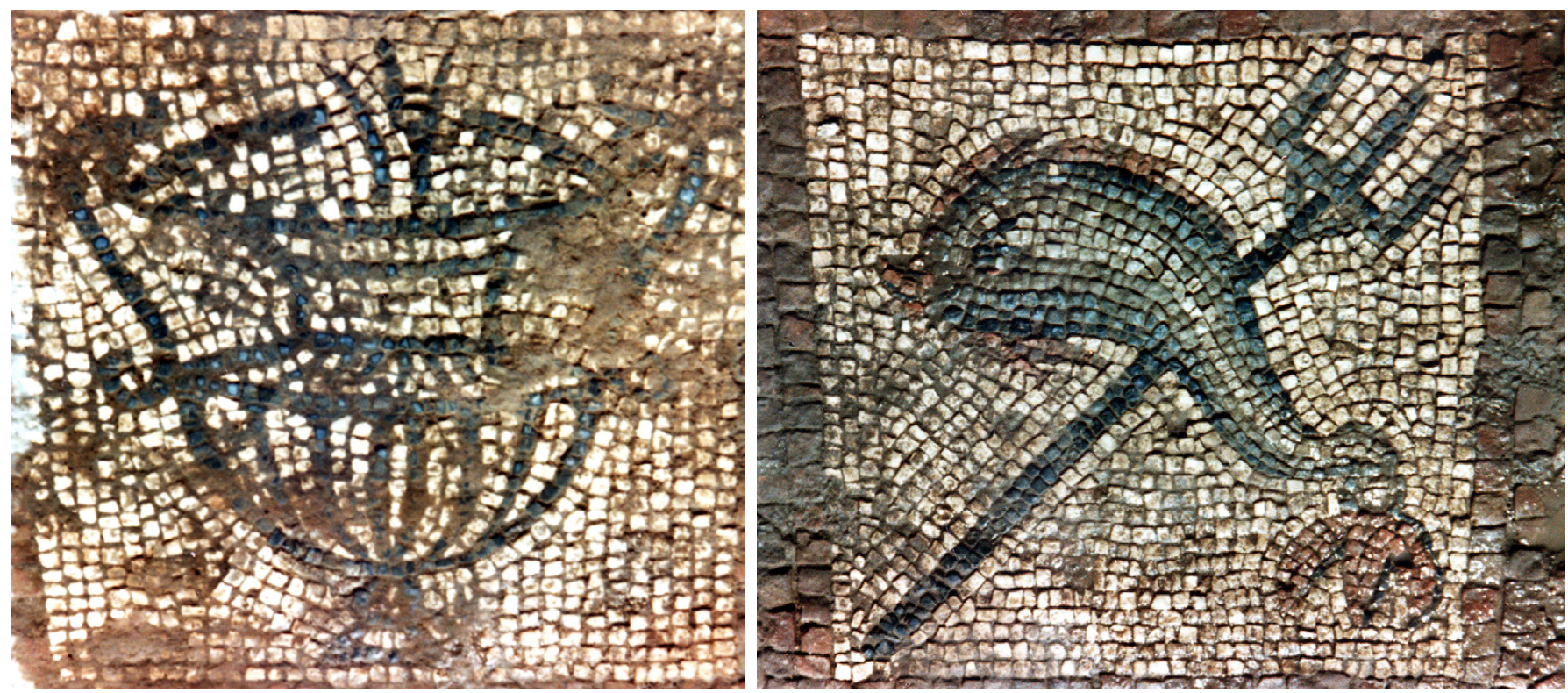

The other mosaic paves a distribution room and presents an elegant geometric field with a central emblem depicting the bust of Oceanus (Fig. 6). The god, with a serene and expressive face, seems to emerge from the sea, which is subtly depicted with simple blue strokes. His thick beard and long hair are drawn in pronounced waves, with crab or crustacean claws and legs protruding from between them².

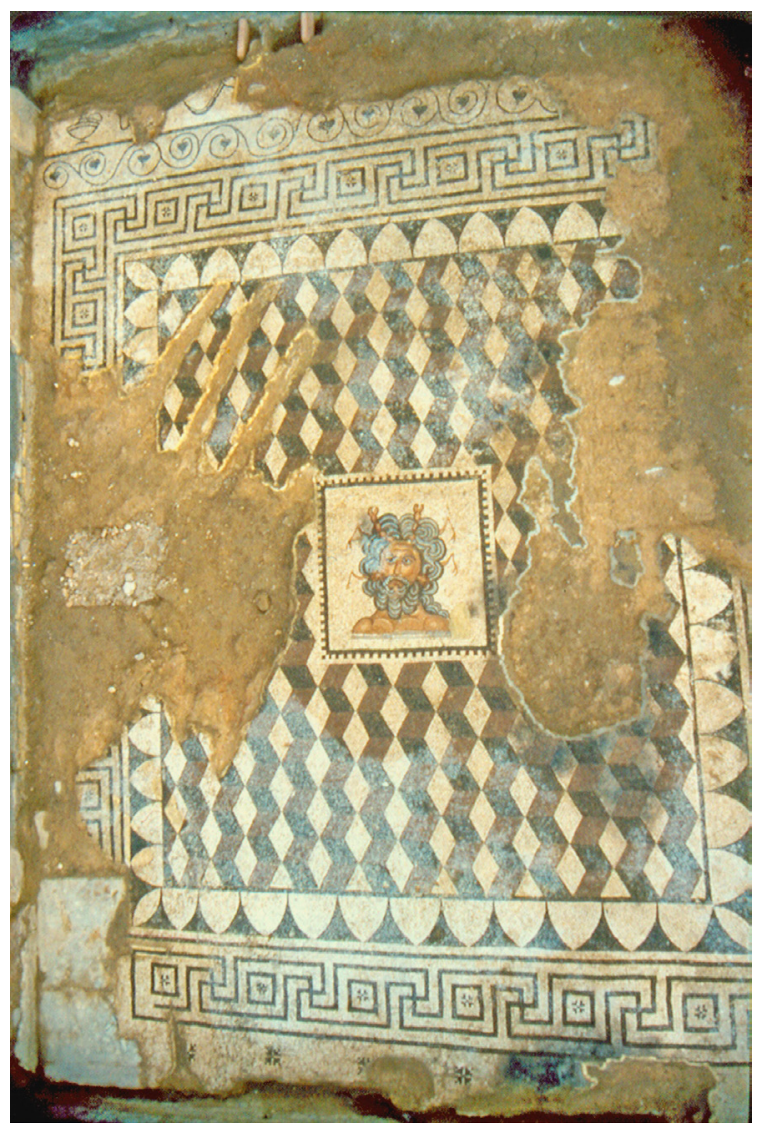

Figures 4 - 5

Details of the Apodoteryum's mosaic of the baths of Santa María de Antequera. Courtesy of Oficina Arqueológica de Antequera.

Figure 6

Mosaic of water distributor of the baths of Santa María de Antquera. Courtesy of Oficina Arqueológica de Antequera.

2 To deepen the study of this mosaic, see Atencia et al. 1990: 220-226; Atencia 1991: 157-159; Romero 1992: 56-62; López Monteagudo 2006: 485-491; Mourão 2010: I, 342-345, 351; II, 174; López Monteagudo 2011: 287-302; Vargas-Vázquez 2016: 60-61; 2018: 315-331. On the iconography of Oceanus see: Foucher 1975: 48-52; Paulian 1979: 115-133; Rodríguez 2011: 541-549; Eraslan 2012: 157-166; 2015: 195-200. 
This wonderful emblem is framed by a well-crafted cube composition. Besides its great sense of character, it is the subtle sensation of undulating and fluid movement that stands out. This is reminiscent of the waves of the sea and it is cleverly achieved by the rotation of the composition, which emphasises the knowledge of the artisans who created it (Vargas-Vázquez 2016: 60-61; 2018: 325).

The decorative elements located in the space that occupies one of the thresholds that gave access to the room are also remarkable and are clearly linked to the thermal activity. They represent a container for oils and/or ointments, a strigilis and part of a sandal. The other sandal was lost due to a breakage of the tessellated surface (Vargas-Vázquez 2016: 60; 2018: 324).

\section{Documented Mosaics in Rural Areas}

\section{Roman villa of Bobadilla}

One of the greatest Roman villae located in Antequera is Bobadilla (Romero - Vargas-Vázquez 2017: 119-138); the mosaics ${ }^{3}$ were discovered in 1891 by Mr. Antonio Aguilar y Correa, Count of Bobadilla and also Marquis of Vega de Armijo, on the land of his property (Aguilar 1892: 100). From the moment of their discovery, the mosaics were subjected to many alterations and changes, which in some cases resulted in the loss of some of the perimeter borders. On another note, the fact that they were extracted without being part of any documented study makes the configuration of the villa itself very difficult to understand. In contrast, the archaeological work carried out in 2004 prior to the construction of the Córdoba-Málaga High Speed Line led to the discovery of the Necropolis and the Alfa of Arroyo Villalta; these are well-studied complexes that have been clearly associated with the Roman villa of Bobadilla (Fernández - Romero 2007: 401-432; Fernández et al. 2010: 177-200).

At the time of the discovery of this villa, four mosaics were found (Rodríguez 1988: 141), of which only three are currently preserved; these were deposited in the warehouses of the Archaeological Museum of Córdoba, except for the emblem with the representation of Priapus. This is displayed in a completely separated way from the rest of the mosaic in the 'Customs Museum' in Málaga.

Among the three preserved mosaics, one is a black and white exclusively geometric. Its geometric composition shows a grid of intersecting horizontal and vertical bands. The other two are polychrome and had two central emblems. In one of them the emblem has completely disappeared and was framed by concentric borders of interlacing capes, chainlets, ogives and swirls of peltas with Solomon's knots in the interior. The mosaic also has a geometric field of secant and tangent octagons. The second emblem is located inside a geometric design of crosses framed by rhomboids and cubes, which gives the pavement a clear and marked three-dimensional effect. As a secondary decorative element, Solomon's knots and braids of two strands stand out (Vargas-Vázquez 2016: 78-81).

The emblem, which stands out for its rich polychromy, shows a representation of the god Priapus, standing in a frontal position, young and beardless (Figs. 7-8). The god is holding up his cloak with both hands, in the manner of a basket, to contain fruit and flowers, revealing his large erect phallus. The image of the god

3 An examination of these mosaics in Rodríguez 1987; 1988: 137-169; Vargas-Vázquez 2016: 78-81; Romero - Vargas-Vázquez 2017: 119-138. 

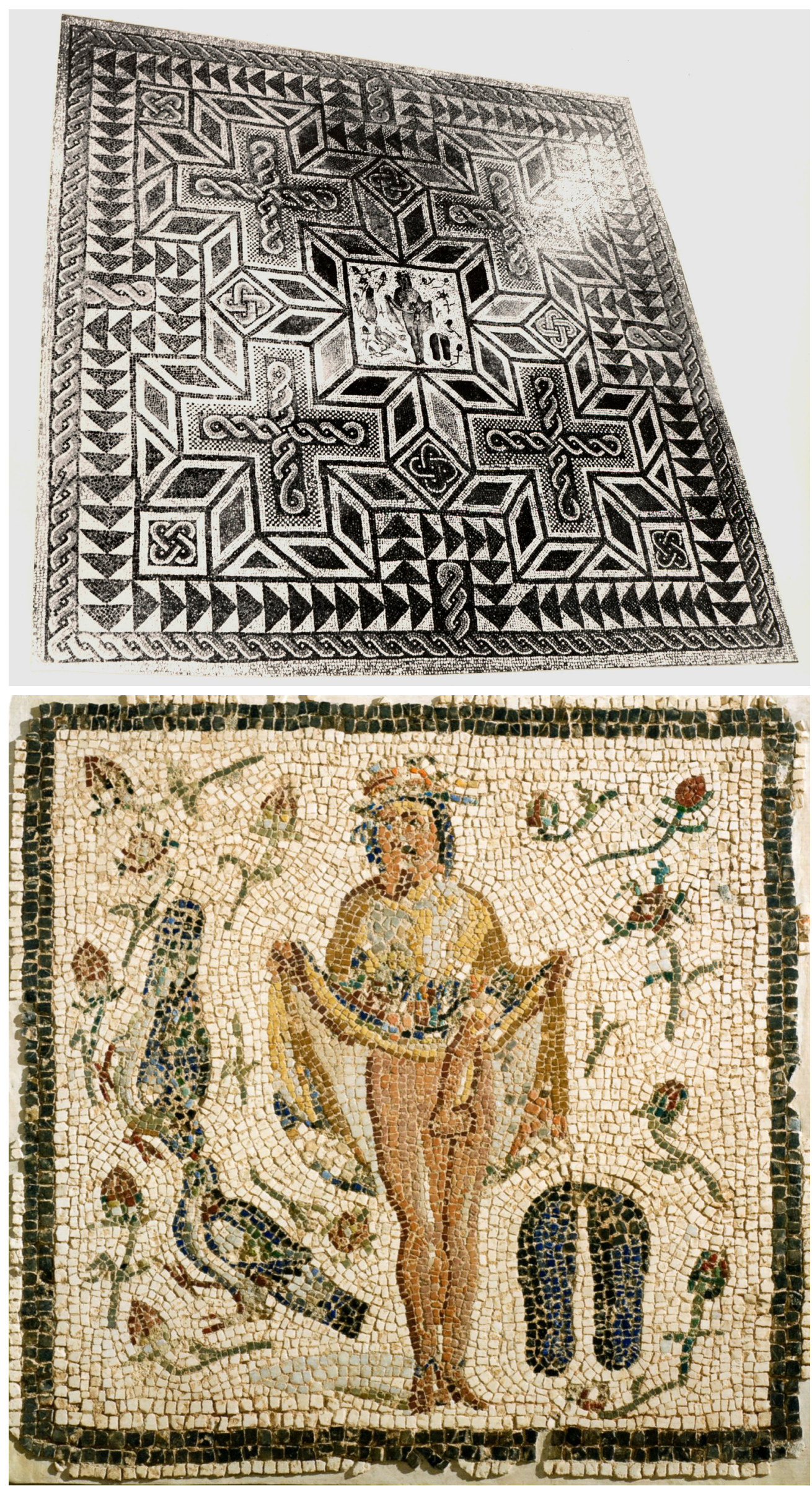

Figure 7

Priapus Mosaic in the Roman villa of Bobadilla. Courtesy of $\mathrm{P}$. Rodríguez Oliva.
Figure 8

Detail of Priapus Mosaic in the Roman villa of Bobadilla. Courtesy of Oficina Arqueológica de Antequera. 
Figure 9

Mosaic of the Roman villa of Carnicería de los Moros. Riñones 1989.

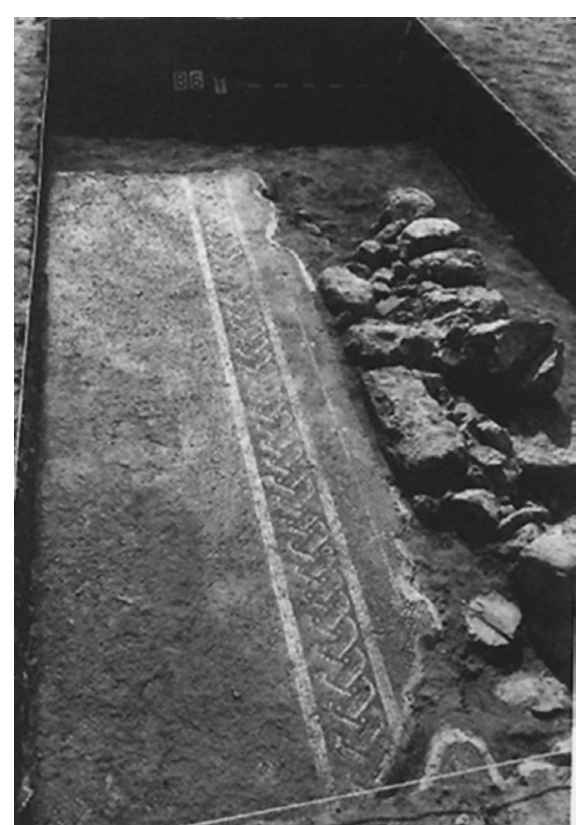

is accompanied by two birds facing each other with their beaks joined together and red rosebuds that symbolically complement the allusion to fertility as they may stand as a female symbol, like Priapus stands as a male symbol, and the representation of a pedum plant, which enhances the prophylactic and beneficent nature of the representation. To this could be added, as symbolic elements, the Solomon's knots and the braids of capes. These mosaics have been dated to a period between the end of the second century and the first half of the third century, probably during Severian times ${ }^{4}$.

With regard to the rooms these mosaics may have paved, we cannot say anything about them for the reasons stated above. However, it is very likely that the Priapus mosaic paved one of the noblest spaces of the Roman villa. In the case of the mosaic with the disappeared emblem, judging from the configuration of its pavement, with a less decorative geometric mosaic surface on one side, we could venture to say it could be the pavement of a bedroom. This area would then have been the place where the bed stood, although such a placing is not necessarily always the case.

As it has been possible to verify in the mosaics of the Roman villa of Bobadilla, geometry acquires great prominence and especially so in the case of pavements with figurative emblems, acting here as an unsurpassed framework. As for the vegetation decoration, it is practically absent; it is only seen framing and accompanying the representation of the god Priapus.

Along with the findings of the mosaics, the Marquis of la Vega de Armijo refers to other outstanding materials found in the surroundings of the villa. Among them we can find some vessels and a white marble mask (Aguilar 1892: 100), a copper cup, a ram-shaped façade-crowning made of bronze, the base of a herm with an inscription (Rodríguez 1988: 140-141) and pieces of mosaics, which show that the villa originally contained more spaces paved with mosaics.

\section{Roman villa of Carnicería de los Moros}

The Roman villa of Carnicería de los Moros was partially excavated in 1984 by Mr. Antonio Riñones Carranza (Riñones 1987: 251-256; 1989: 1081-1090). It is very likely that when the excavation is completed it will become one of the most wondrous villae of the Iberian Peninsula. At the moment, little it is known about it, but it shows evident signs of luxury and monumentality. With its extraordinary and grand front formed by a front wall with a series of apses, the villa is reminiscent of the Mysteries of Pompeii; this is definitely its most impressive part. From this wall a large pond extends, 53.85 x $11.55 \mathrm{~m}$, which at other end, borders a large porticoed gallery, paved with the only mosaic of the villa that has been found so far, a large tessellated surface over $50 \mathrm{~m}$ long and 3.70 $\mathrm{m}$ wide. The mosaic, which turns $90^{\circ}$ at one end, could constitute the pavement of a large peristyle, although the current state of the investigation does not allow ensuring or expanding in this regard. Of this large pavement, only a number of isolated pieces are preserved, such as a perimeter band of ceramic tesserae, a white line decorated with equidistant knots and a polychrome border decorated with a three-strand braid. Its interior section is defined by a wide smooth carpet of ochre or yellow tesserae (Fig. 9), in which the complete absence of decoration stands out strongly (Vargas-Vázquez - Romero 2016: 418-422).

4 For the study of this mosaic, see Rodríguez 1987; 1988: 137-169; Blázquez 2008: 107-115; López Monteagudo 2010: 160-161; Vargas-Vázquez 2016: 79-80; Vargas-Vázquez - López Monteagudo 2016: 430 fig. 15; Romero - Vargas-Vázquez 2017: 119-138. 


\section{Roman villa of La Estación}

The residential complex of this majestic Roman villa, of suburban character, is imposing. The complex is partially excavated and is articulated around a peristyle with a large pond, in which four islets were found (three of them were excavated). These islets were built with circular and decorated alcorques with a diameter of $4 \mathrm{~m}$ probably decorated with vegetal motives and sculptures. In the immediate vicinity, a few metres beyond the residential complex, is the balneum. In between, probably surrounded by a garden area, a beautiful nymphaeum is located (Fig. 10). All of the mosaics documented in this villa are concentrated to the residential complex, while in the case of the balneum they have not been preserved. Tesserae made of glass paste were found in the nymphaeum, which may have been covered by them.

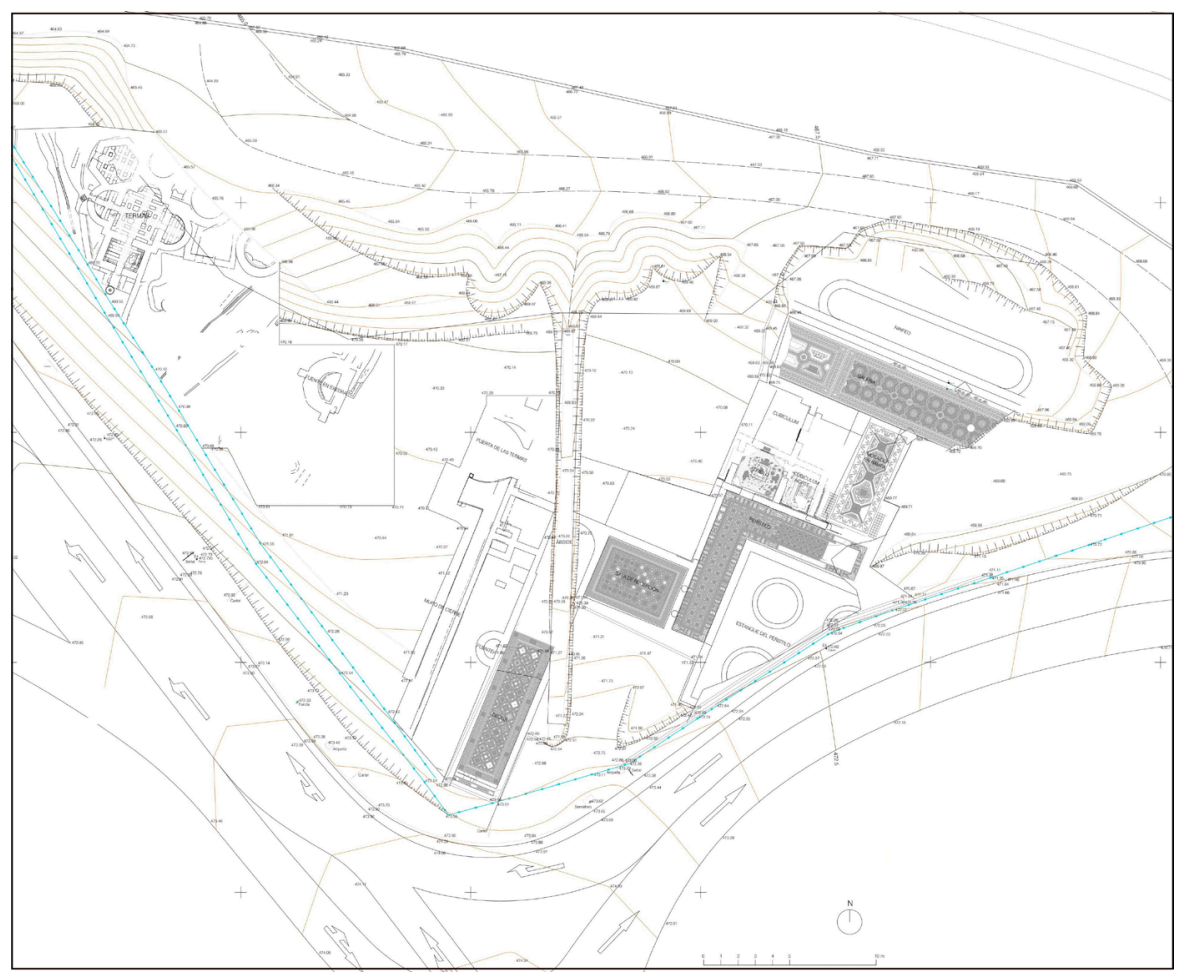

The pavements of the villa are distributed almost throughout all the spaces, oecus, galleries and corridors - mosaic of the peristyle gallery, ramp gallery mosaic, mosaic of the porticoed gallery, mosaic of the great gallery or corridor, and a more private area of the villa that contains the compluvium mosaics of the small atrium, that of the corridor and others probably associated with cubicula ${ }^{5}$.

All these paved areas are characterized by the use of geometric mosaics, which in some cases denote impeccable work, as evidenced by the mosaics of the oecus (Fig. 11) and the porticoed gallery (Fig. 12), as well as by the predominance of polychromy. As an exception those of the most private area could be mentioned; these are characterized by a more extensive use of black and white, although in some of them slight colour notes are introduced into the decorative elements (Fig. 13).

5 An examination of these mosaics in Romero et al. 2006: 239-258; Mañas - Vargas-Vázquez 2007: 315-338; Romero et al. 2010: 3569-3590; Romero - Vargas-Vázquez 2016: 437-447; Vargas-Vázquez 2016: 62-77.
Figure 10

Plan of the Roman villa of La Estación. Courtesy of Oficina Arqueológica de Antequera. 
Figure 11

Oecus mosaic of the Roman villa of $\mathrm{La}$ Estación. Courtesy of Oficina Arqueológica de Antequera.

Figure 12

Mosaic from the porticoed gallery of the Roman villa of La Estación. Courtesy of Oficina Arqueológica de Antequera.

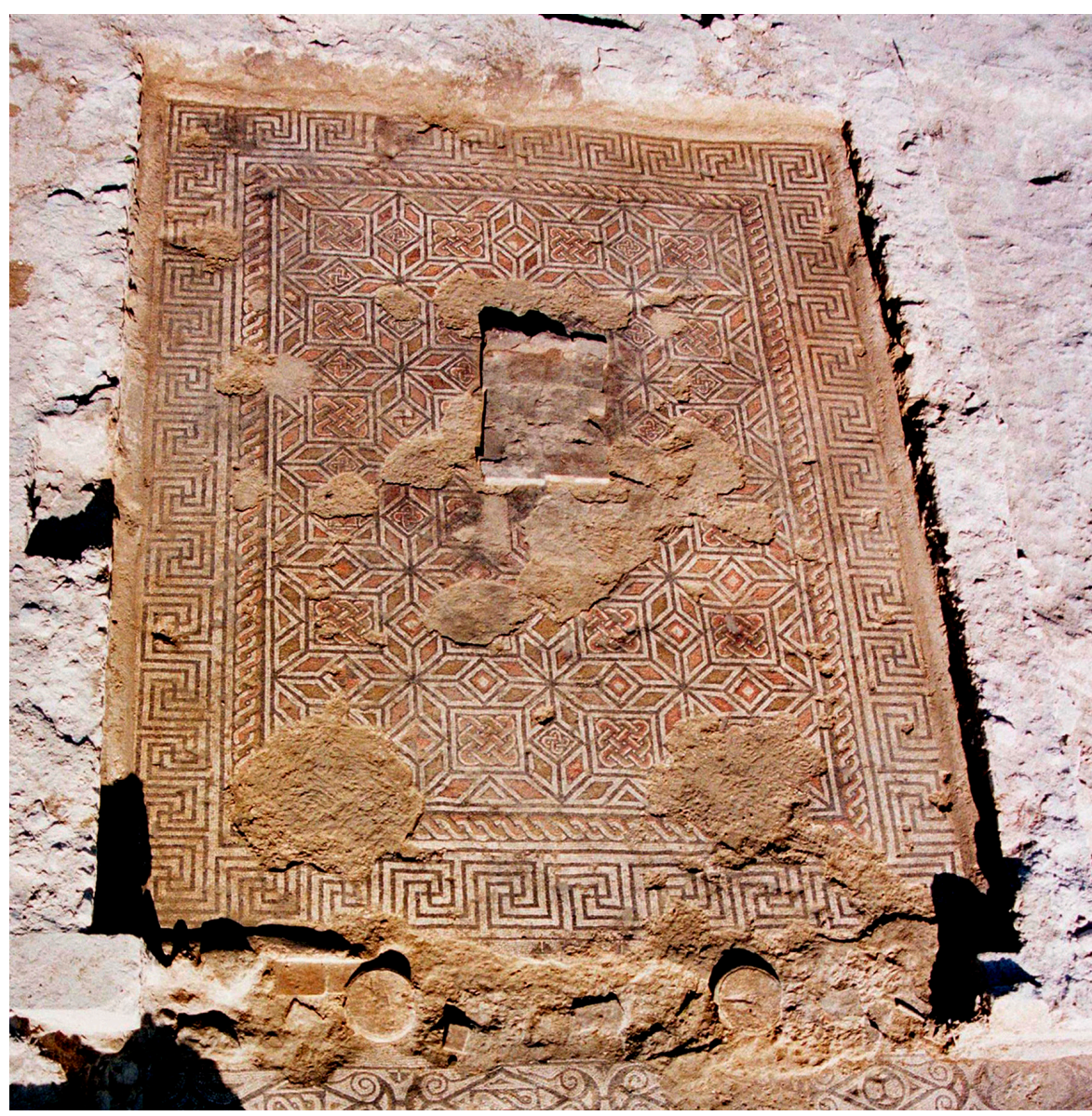

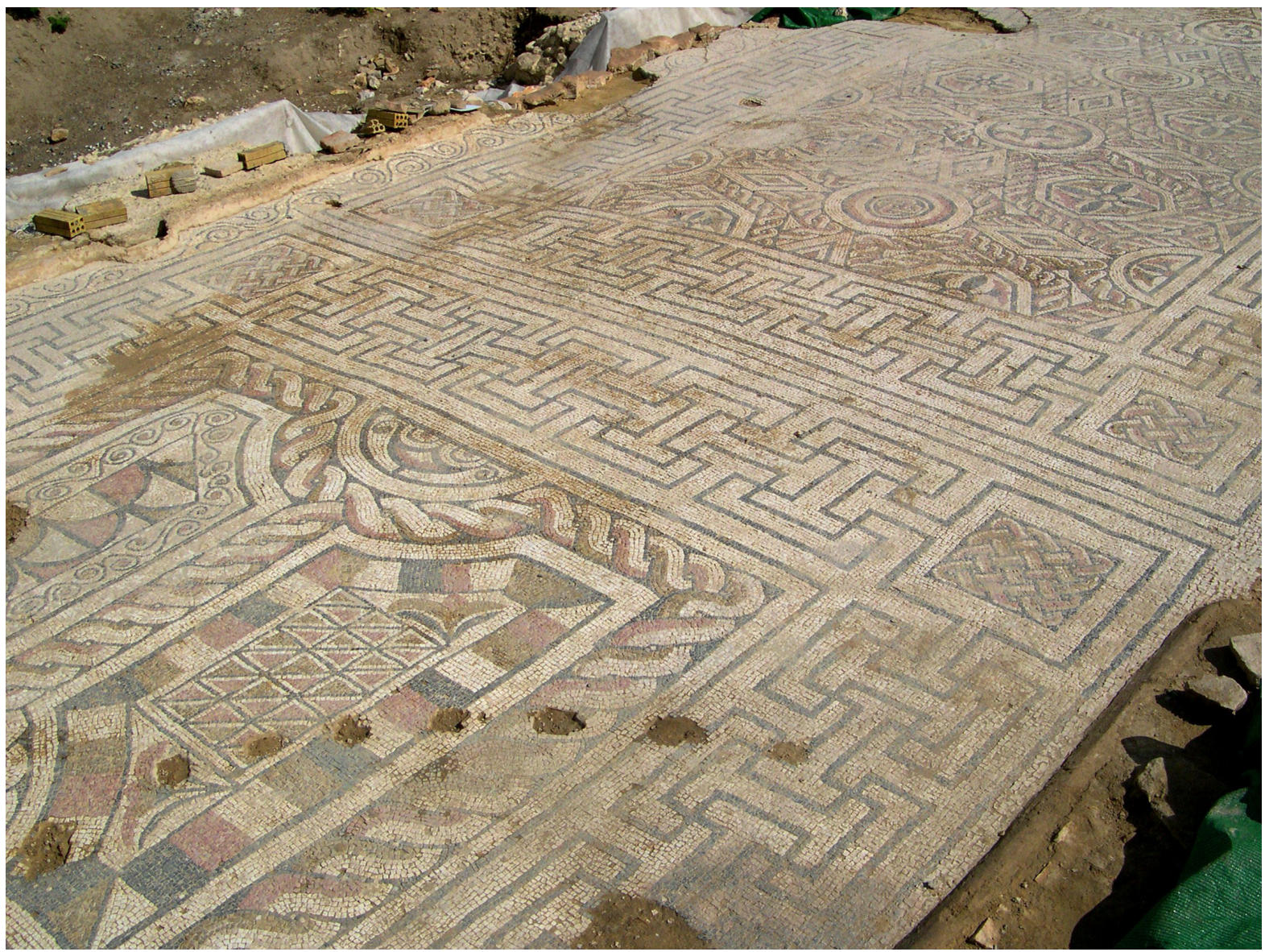




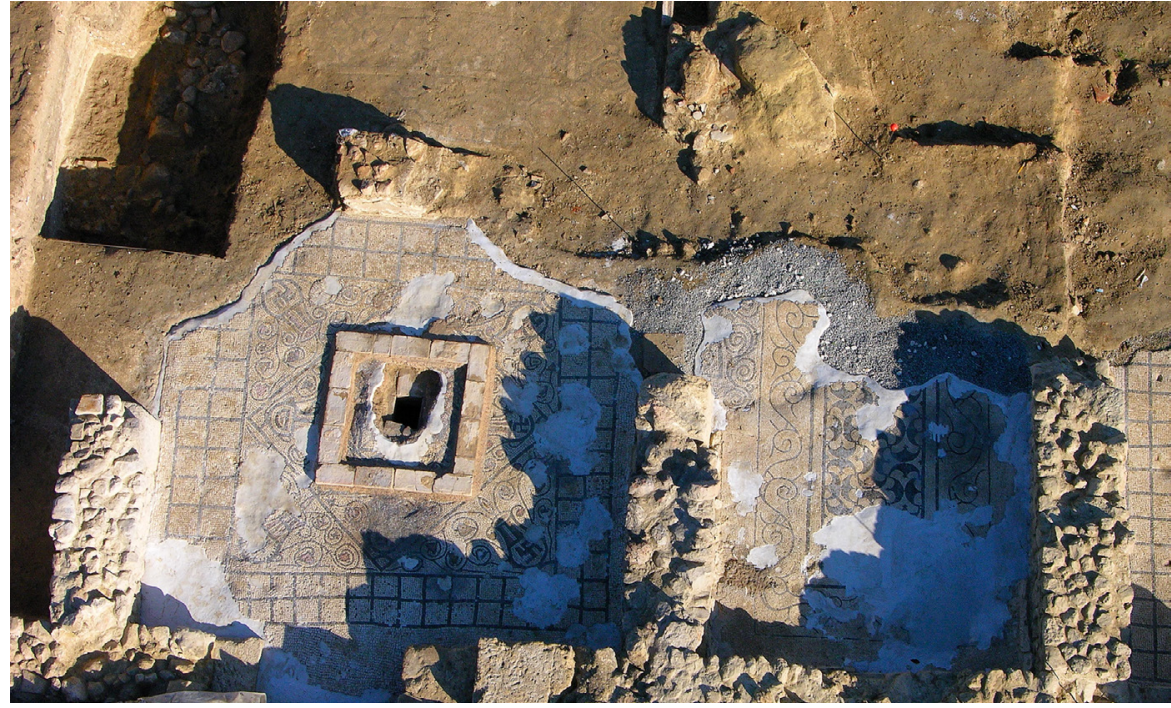

This difference in the polychromy of the pavements could simply be due to the aforementioned differentiation of spaces, because the least colourful were reserved for the most private spaces and were less trodden by people invited to the villa. It could also be due to the fact that different workshops were involved in their making. The chronology of the whole complex would be framed between the end of the third century and the first half of the fourth. The latter date would almost certainly be the period when the pavements of the private area were in use. Within the mosaics of the villa de La Estación, the floral element is located only in the geometric spaces of the mosaics, and in the borders. An exception is the mosaic of the atriolum, in which the rinceau of hedera that sprout from the craters surround the entire space (Fig. 14).

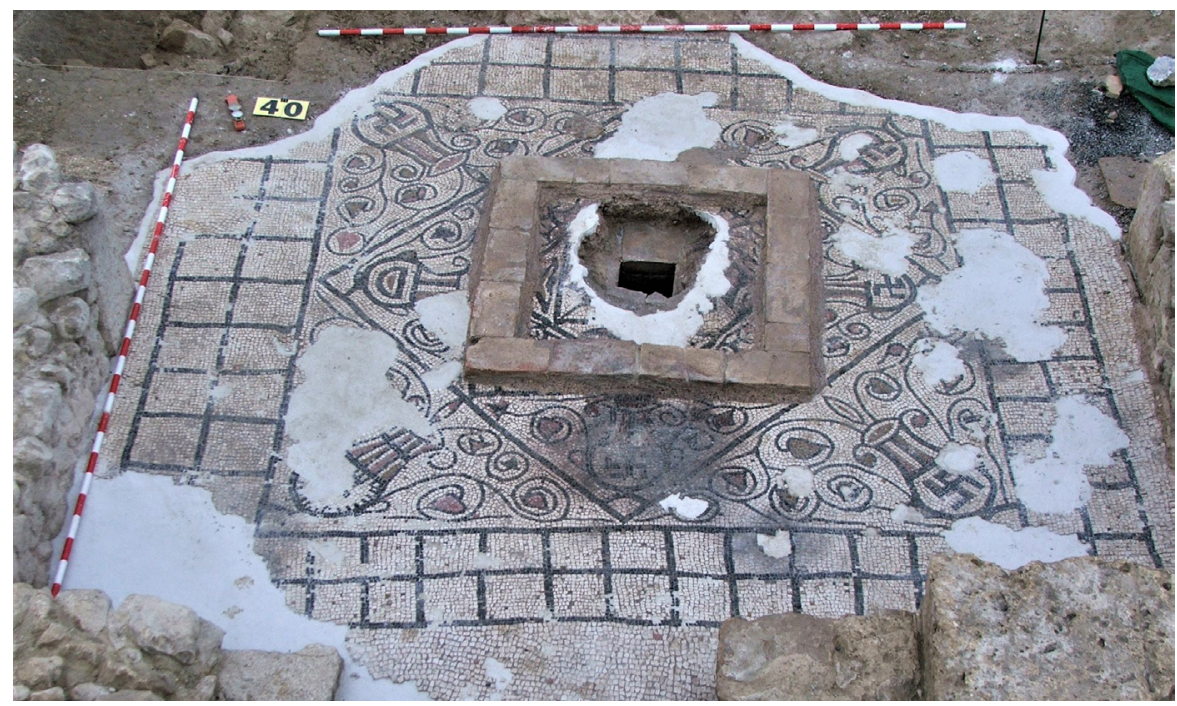

Apart from this last case, we can say that there are no mosaics with large fields of foliage, neither with geometric-floral patterns nor with a clear predominance of floral elements. This is not common to find in the rest of Roman Baetica. A remarkable decorative element in these mosaics can be seen on the craters of one of its pavements; the sides of the craters are decorated with swastikas.

From the figurative point of view, the only mosaic that shows a small representation of Erotes is located in an area immediately next to the pond and adjacent to the porticoed gallery (Fig. 15). It is covered and abandoned
Figure 13

Mosaics from the private area of the Roman villa of La Estación. Courtesy of Oficina Arqueológica de Antequera.

Figure 14

Mosaic from the Impluvium of the small atrium of the Roman villa of La Estación. Courtesy of Oficina Arqueológica de Antequera. 


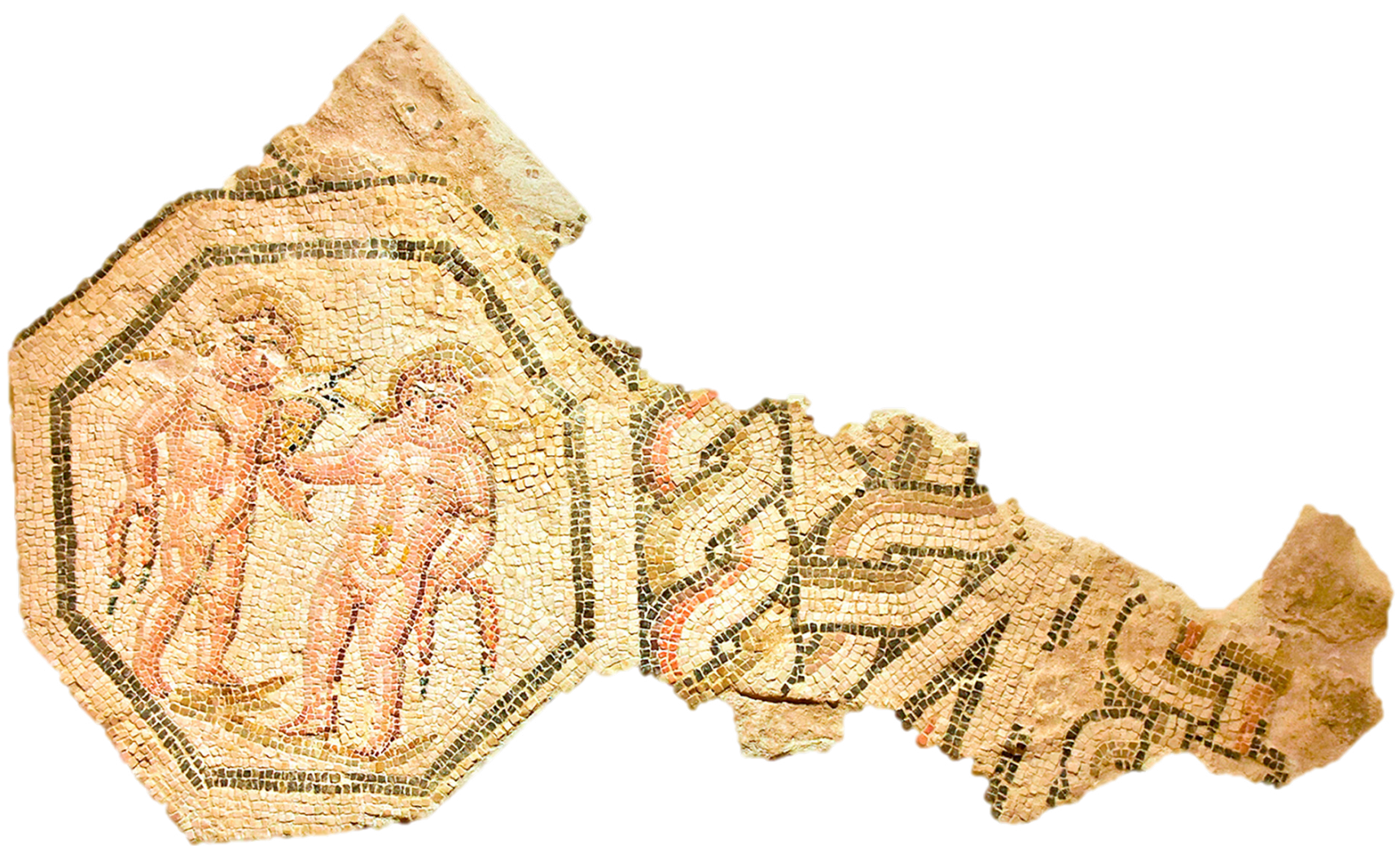

Figure 15

Erotes mosaic of the Roman villa of La Estación. Courtesy of Oficina Arqueológica de Antequera. and belongs to an earlier time frame of the villa, still undetermined today. The representation in question shows two erotes inside an octagon that was surely part of a much broader modular composition of a mosaic; more than $80 \%$ of this has disappeared (Vargas-Vázquez 2016: 72-73). Thus, it is quite certain that the repertoire of figurative representations of this pavement were greater. They may have been related to Dionysian representations, considering the attitude of both of the Erotes figures, who seem to play with a glass of wine. One of them seems flushed and/or intoxicated (Mourão 2010: I, 258-259; II, 175; Vargas-Vázquez - López Monteagudo 2016: 427). Both winged erotes are depicted standing, with straight hairstyles that seem to be inspired by Constantinian or Theodosian images. They hold a garland or diadem in one of their hands (Mañas - VargasVázquez 2007: 324-325).

Outside this area of the villa, also covered and abandoned during its last time frame, the figurative element is entirely absent in the mosaics discovered so far. It is reserved for sculpture and other elements such as antefix, and also most likely for parietal decoration, as the parietal sectile documented in the northern cubiculum shows (Fig. 16). It was also reserved for a wall painting that was obviously lost to a large part with the deterioration of the walls, although there are some fragments left with another type of decoration. It is also an interesting possibility that some of the walls of the villa were covered with parietal mosaics, at least partially. This could be suggested by some fragments of dissociated mosaics that have been preserved and that show a completely different typology to those that pave the different spaces of the villa. To this is added the presence of numerous glass paste tesserae, of different colours, which are completely absent in the mosaics documented until now in the architectural complex. In this sense, the presence of a good number of translucent tesserae coated with a thin layer of gold paste is tremendously significant to attest the wealthiness of the landlord and the luxurious decoration of the villa (Romero - Vargas Vázquez 2012: 823-828; Vargas-Vázquez 2016: 305-307). If it is admitted these tesserae 


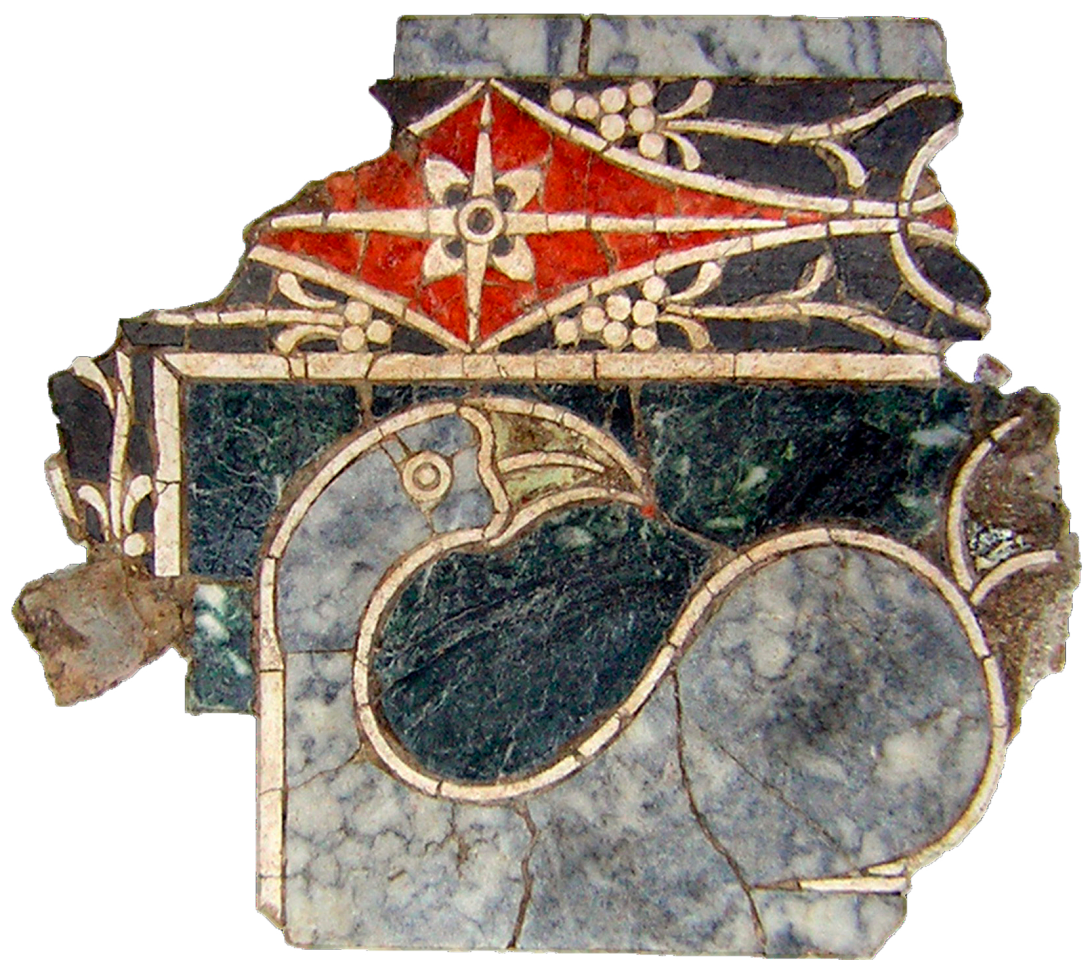

and fragments of mosaics were not part of wall coverings, then it must exist elsewhere luxurious mosaics that was not found until now. Currently only $20 \%$ of the excavation is completed, and presumably preserved spaces and mosaics more luxurious than those already discovered, could be found.

\section{Roman villa of Caserío Silverio}

Another of the villae near the city of Antequera is the one of Caserío SilverioMayorga (Fig. 17), subject of a preventive archaeological intervention motivated

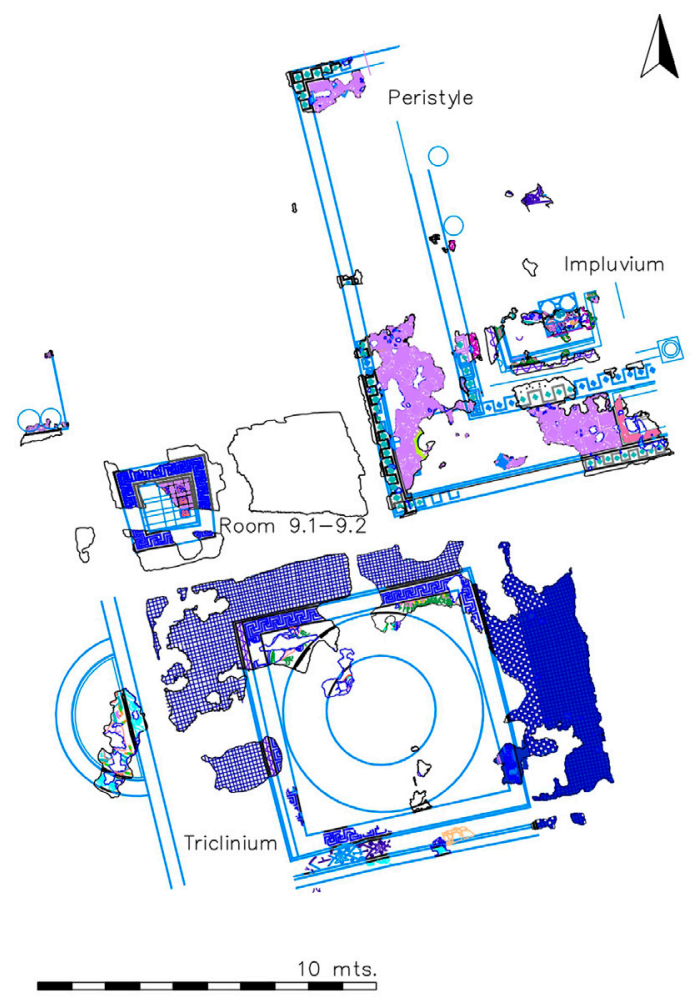

Figure 16

Parietal opus sectile of the Roman villa of La Estación. Courtesy of Oficina Arqueológica de Antequera.
Figure 17

Pars urbana of the Roman villa of Caserío Silverio. Courtesy of Oficina Arqueológica de Antequera. 
Figure 18

Mosaic fragment from the peristyle's gallery of the Roman villa of Caserío Silverio. Courtesy of Oficina Arqueológica de Antequera.

\section{Figure 19}

Detail of the mosaic fragment from the peristyle's gallery of the Roman villa of Caserío Silverio. Courtesy of Oficina Arqueológica de Antequera. by construction of the high-speed train line between the years 2011 and 2012 (Espinar et al. 2014: 66-97; 2016: 423-430). It is a large rural complex in which the mosaics once again are assigned great importance ${ }^{6}$. This new villa has an interesting mosaic repertoire, dated to a period between the third and fourth centuries (Vargas-Vázquez - Romero 2014: 164). Figurative representations, more numerous than in any other Antequeran villa, played a leading and very prominent role, especially the paving of the triclinium (room 6). Other mosaics were found in the peristyle galleries, in the impluvium zone, in the rooms 9.1-9.2 and in the triclinium (Fig. 17). In other spaces, minimal although relevant signs of mosaic decoration are preserved, which show that the villa had many more mosaics (Vargas-Vázquez - Romero 2014: 138-167).

In the peristyle galleries, a wide geometric frame covers the entire surface. In it, some spaces are reserved for figurative representations; circular medallions are found in the corners of the galleries, as well as quadrangular emblems located in the centre of the latter. Only one of the four medallions that must have belonged to the mosaic retains minimal clues to the presence of a female character (Figs. 18-19). Its hairstyle is reminiscent of certain muses and also of the hairstyles usual for the nymph Amymone or the nereid Amphitrite, with hair in a high bun, headband or crown, and, at the same time, with hair that falls on her shoulders. The goddess Venus is sometimes also presented with this type of hairstyle, and even Tethys, so it is probably a character related to water. The remaining medallions, currently lost, must have similar representations (Vargas-Vázquez - Romero 2014: 152-156). In the case of the boxes located in the centres of the peristyle galleries, only one has been preserved, but the representation that it contained is practically all lost.
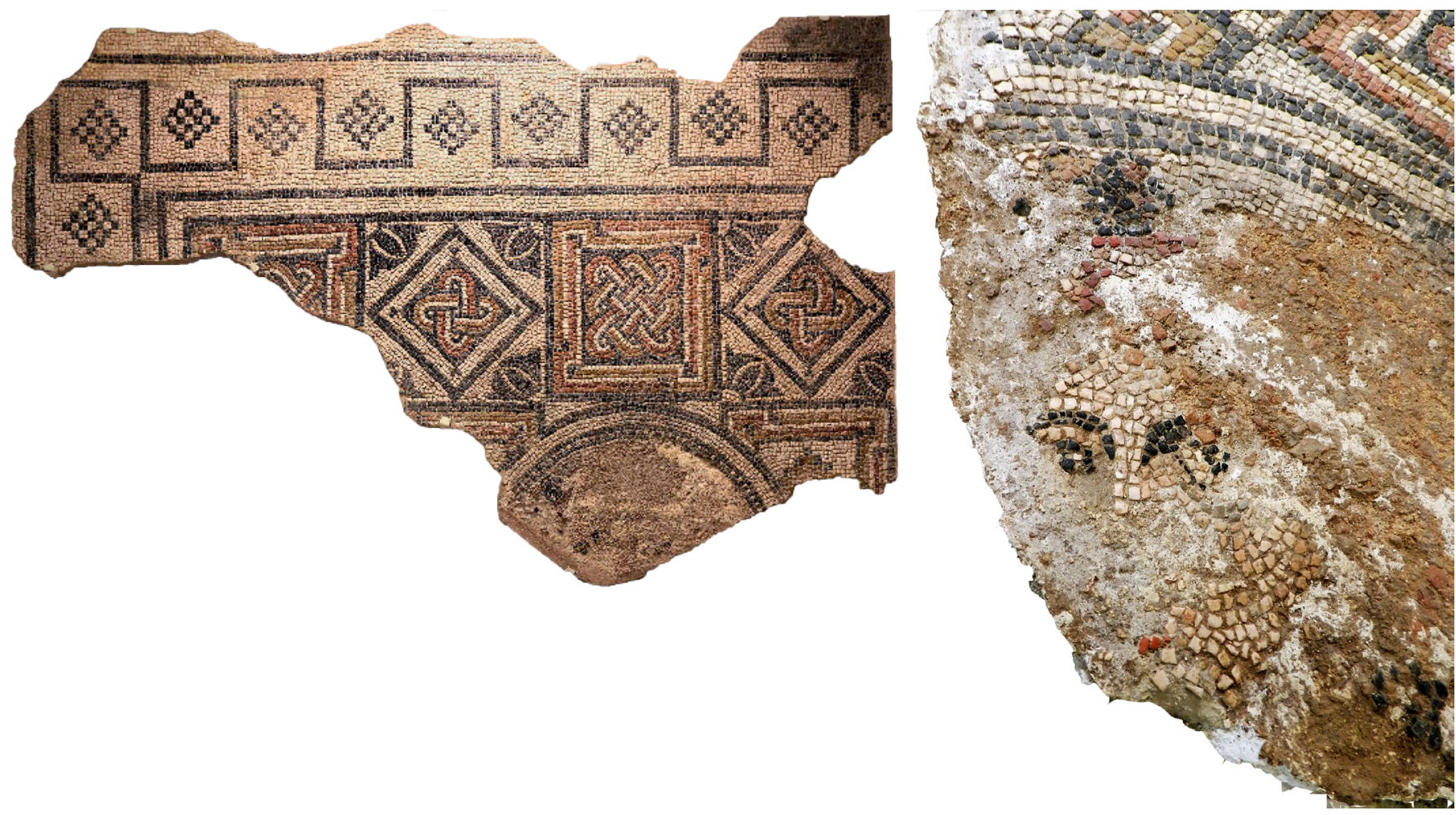

6 For a broader view of this villa's mosaics, see Vargas-Vázquez - Romero 2014: 138-167. 
The impluvium mosaic, shows a less noticeable colour than the rest of the mosaics of the villa. The same difference in polychromy is also detected in the execution of representations exhibited on the pavement, which denote less dexterity and realism. In the deteriorated pavement was found a scene without internal divisions related to water; the scene could depict a dolphin, the water is represented by small serrated lines, and a circle circumscribes a flower with six petals. Another section, which is a continuity of the former, is also poorly preserved. Its decoration has a prominent composition of tangent octagons. Judging by the preserved elements, it is probable that geometric figures, fish and waterfowl were represented inside these octagons (Vargas-Vázquez - Romero 2014: 156-159).

The mosaic of room 9.1-9.2 appears to have numerous lost parts and no evidence of figurative representation can be discovered. However, its general configuration, composed of a small geometric field inserted in a large carpet of ceramic tesserae is attractive, as in the case of the mosaic of the baths of Santa María.

Room 6, identified as the triclinium (Figs. 20-21), is the one that undoubtedly has the most significant mosaic of the entire architectural complex (VargasVázquez - Romero 2014: 139-148). The room also has two exedras opening in the southern and western wall. In the latter, mosaic remains have been preserved, while in the other no remains have been left even if they may ever existed. In the mosaic of the exedra, the figurative representation is distributed throughout the mosaic surface, contoured by a border with waves or poles, and without any geometric division.
Figure 20

Triclinium of the Roman villa of Caserío Silverio. Courtesy of Oficina Arqueológica de Antequera.

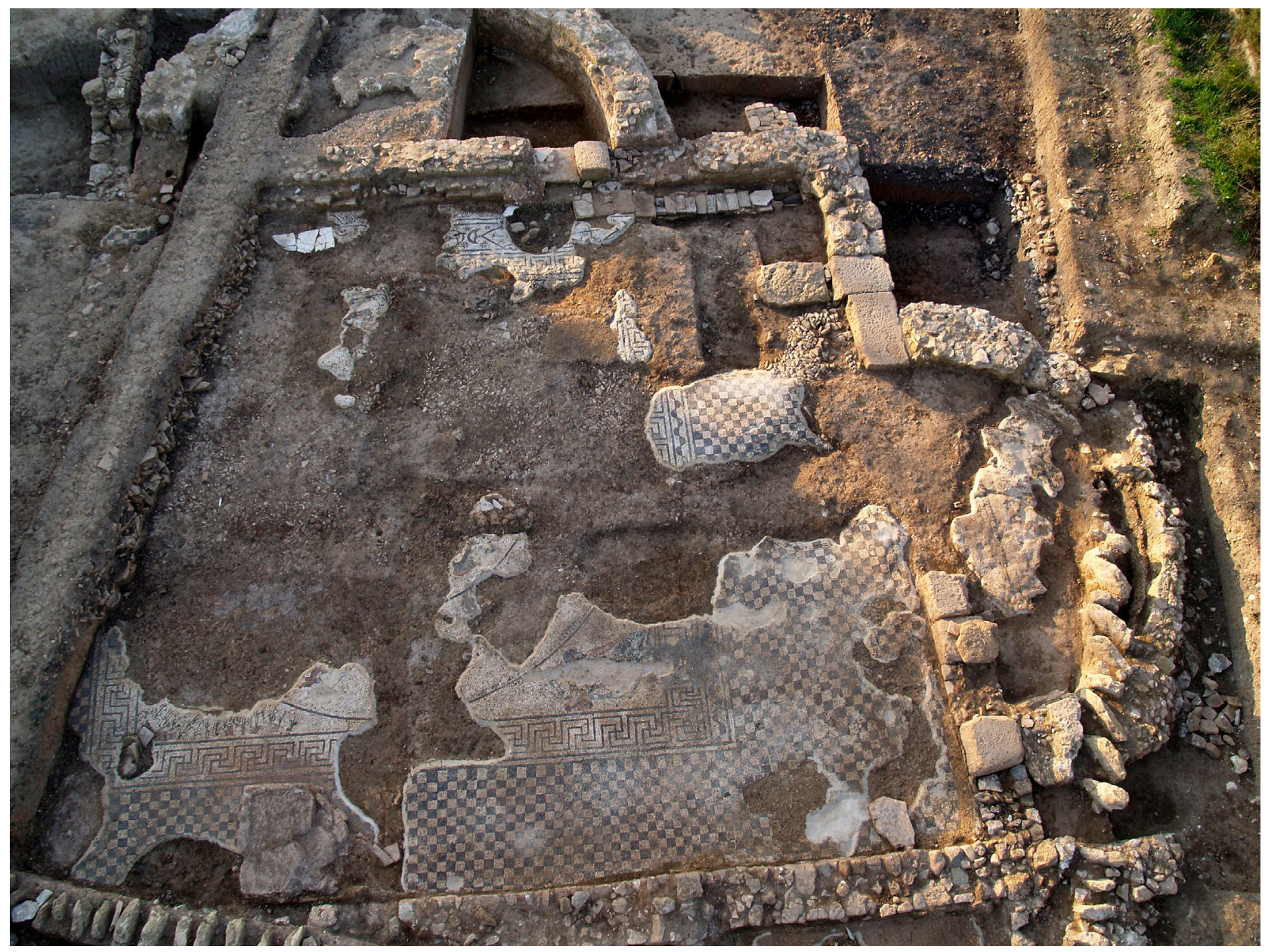


Figure 21

Drawing of the triclinium of the Roman villa of Caserío Silverio. Courtesy of Oficina Arqueológica de Antequera.

Figure 22

Detail of the triclinium of the Roman villa of Caserío Silverio. Location of epigraphs. Courtesy of Oficina Arqueológica de Antequera.

Figure 23

Mosaic fragment from triclinium depicting Tiber and inscription. Courtesy of Oficina Arqueológica de Antequera.
The preserved remains of the mosaic show elements from a clear marine environment, such as a dolphin; a fish and the remains of another; the tail of what could be a hippocampus; and figures that are difficult to define, perhaps molluses such as razor clams. All this surrounds a semi-circular compact element that could well represent an islet or the underground cave itself where Cirene and the nymphs live. This is a clear attempt to continue the discourse and theme represented in the mosaic that paves the entire triclinium, which we will consider in the following.

The triclinium mosaic is undoubtedly the most impressive of the villa (Fig. 20). The pavement has a U-shaped perimetral geometric field, conceived as a large black and white checkerboard, which clearly demonstrates its configuration as a triclinium.

After this, a series of borders give way to a square-shaped central field in which two large concentric circles are drawn, which serve as a framework for figurative representations, unfortunately largely lost (Figs. 20-21). Within this squareshaped, the representation of a river god is preserved in one of the corners or spandrel of the mosaic. Its identification with the river Tiber is easy to define thanks to the partially preserved inscription present on the pavement, which can be seen inside the outermost circle (Figs. 21-23).
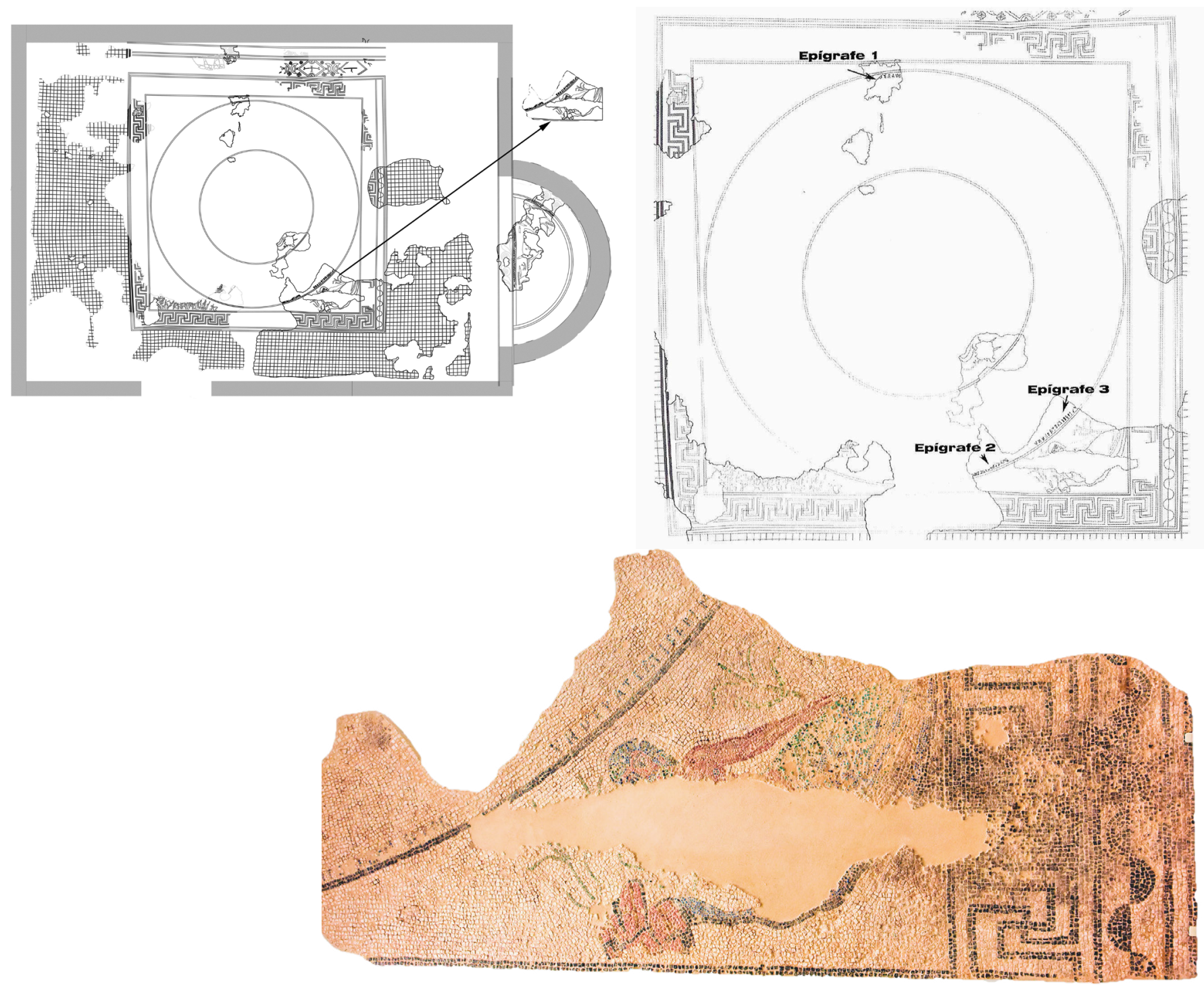
The river god 7 is shown as an elderly bearded man. His torso is uncovered and surrounded by riverside vegetation and reclining next to a rock from which water flows, which would represent the source of the river itself, the Atria Tiberina. His thick hair stands out, with tesserae of blue vitreous paste, as well as the cloak that covers his legs. This depiction would mimic the course of water that rises from the rock and flows beneath the god, serving as a bed for him.

This kind of representation is unknown to us in Hispanic Roman mosaics, although it is the only one whose identification is beyond doubt thanks, as stated before, to the inscription preserved on the pavement. In Roman Hispania, apart from the one we are analyzing, only the mosaic from the House of Medusa at Ferragial d'El Rei (Alter do Chão, Portugal) was identified with the river Tiber (Mourão 2010: I, 327-330; II, 65-66; Caetano - Mourão 2012: 210, 213-216).

Regarding the subject of the mosaic inscription, it can be stated without much doubt that it is a unicum within the Roman mosaic technique. The verses identified are taken from Vergil's Georgics' Book IV (Verg. georg. 337, 353-354, and 369$)^{8}$. The following fragments are preserved (Fig. 22):

Fragment 1 (Fig. 24):

(---)m per c(an?)d(ida---?) (Verg. georg. 4. 337).

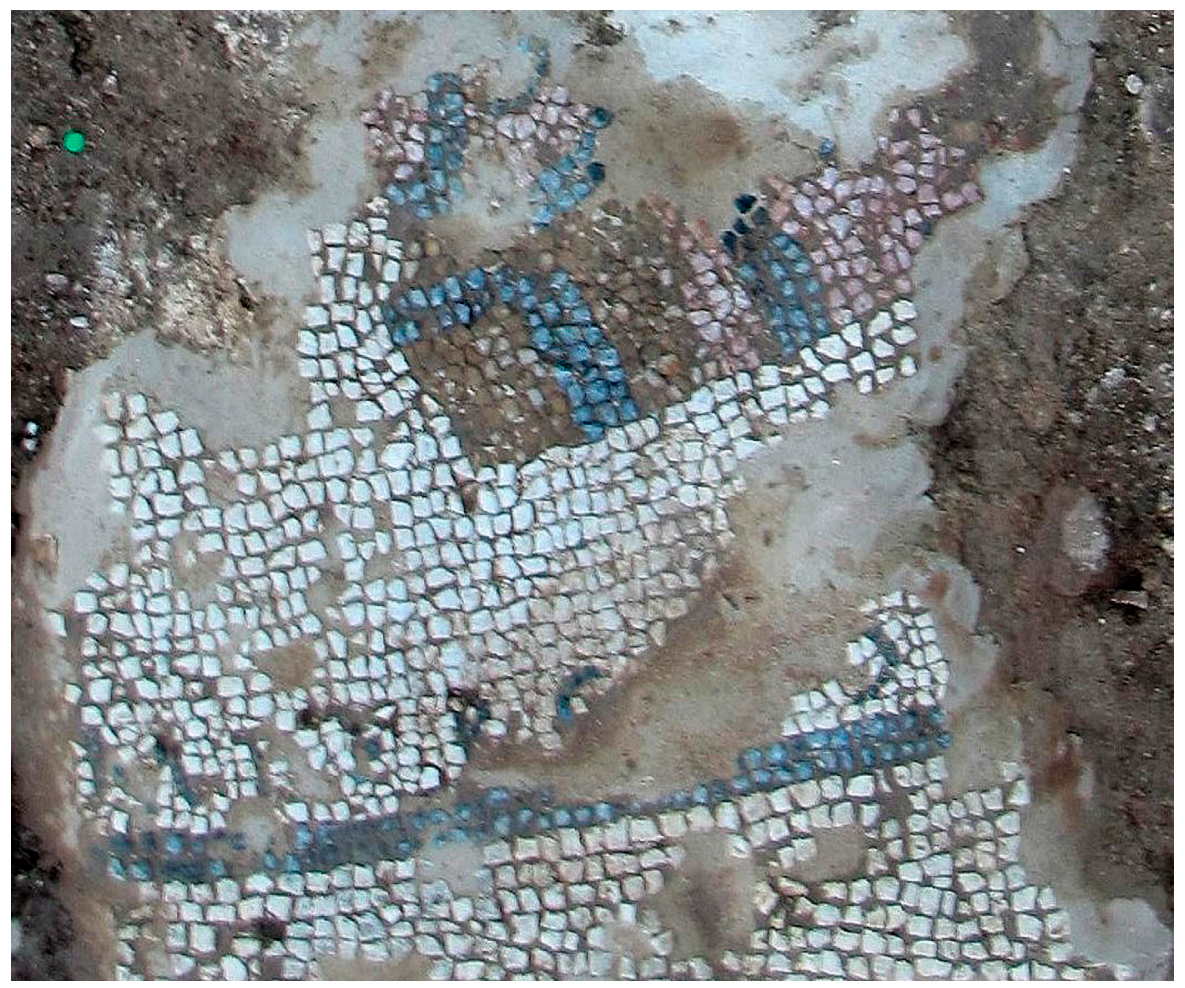

In this fragment, the nymphs are spinning near Cyrene and warned her how Aristeo was showing up with his laments. In addition, the poet describes the headdress of some of these nymphs.

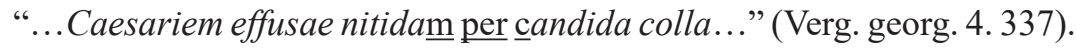

Figure 24

Mosaic of triclinium. Inscription. Fregment 1. Courtesy of Oficina Arqueológica de Antequera.

7 Further reading about the river gods: Gais 1978: 355-370; Ostrowski 1991; Brewster 1997; Montero 2012.

8 See Gómez 2014: 168-178; Vargas-Vázquez - Romero 2014: 139-148. 
Figure 25

Mosaic of triclinium. Inscription. Fregment 2. Courtesy of Oficina Arqueológica de Antequera.
Fregment 2 (Fig. 25):

“(---t) anto cyrene soror” (Verg. georg. 4. 353-354).

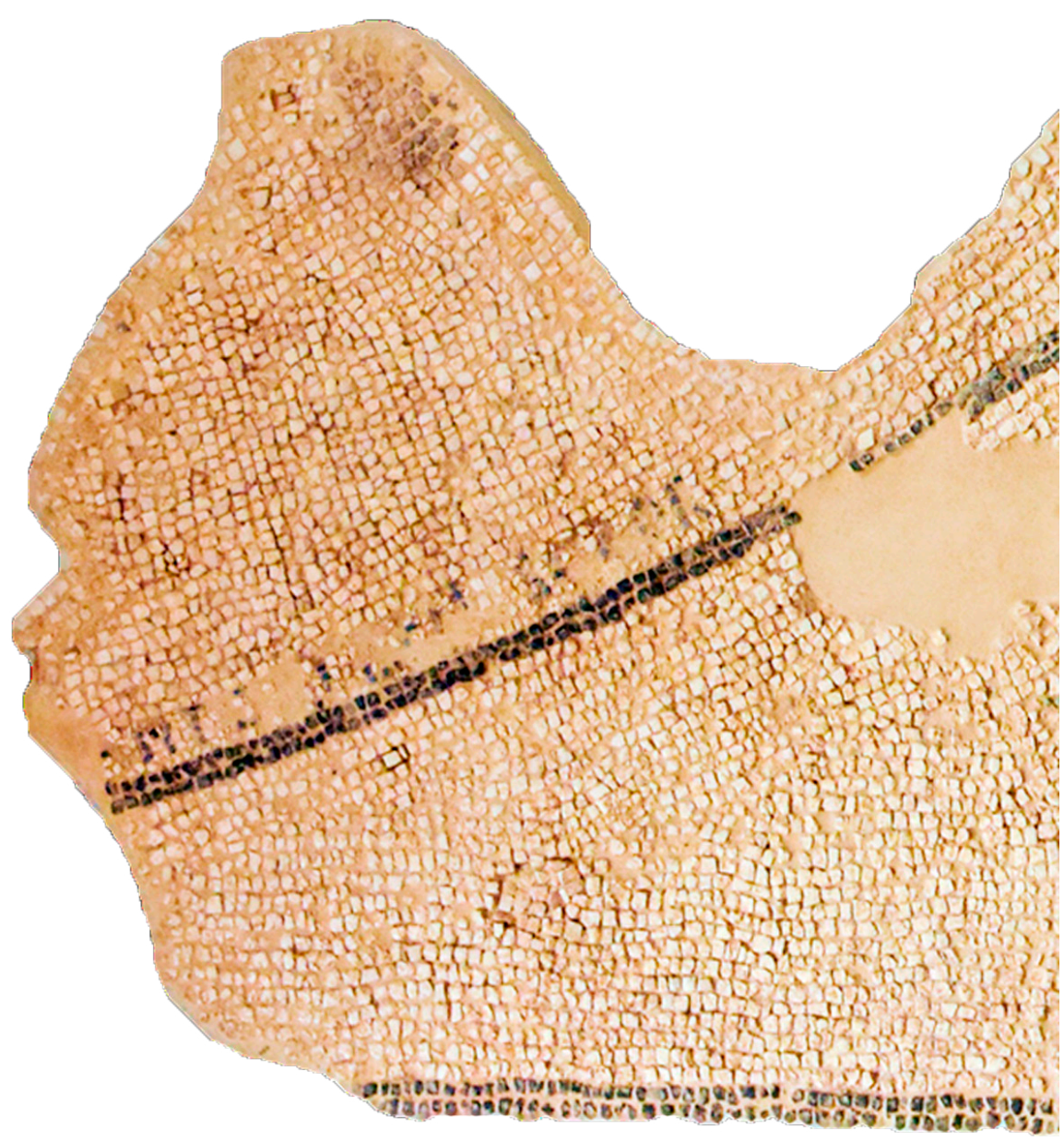

This fragment belongs to the verses where the author describes the moment when Arethusa tells Cyrene that her son is calling her grievously near the river:

"O gemitu non frustra exterrita tanto,

Cyrene soror, ipse tibi, tua maxima cura,

tristis Aristaeus Penei genitoris ad undam

stat lacrimans et te crudelem nomine dicit." (Verg. georg. 4. 353-356)

Fragment 3 (Fig. 26):

"Vnde pater tiberinv (s ---)" (Verg. georg. 4. 369).

Fragment belonging to the part of the text in which Cirene orders the river to open itself to let her son pass. Other rivers are named in it.

Et caput, unde altus primum se erumpit Enipeus,

Unde pater Tiberinus, et unde Aniena fluenta' (Verg. georg. 4. 368-369).

From this part of the text, it can be deduced that the other three spandrels of the mosaic contained other representations of rivers, which, following the guidelines of Vergil's text, could well be the Enipeus, the Aniena and the Eridanus. In one of them, remains of vegetation associated with the river were preserved. 


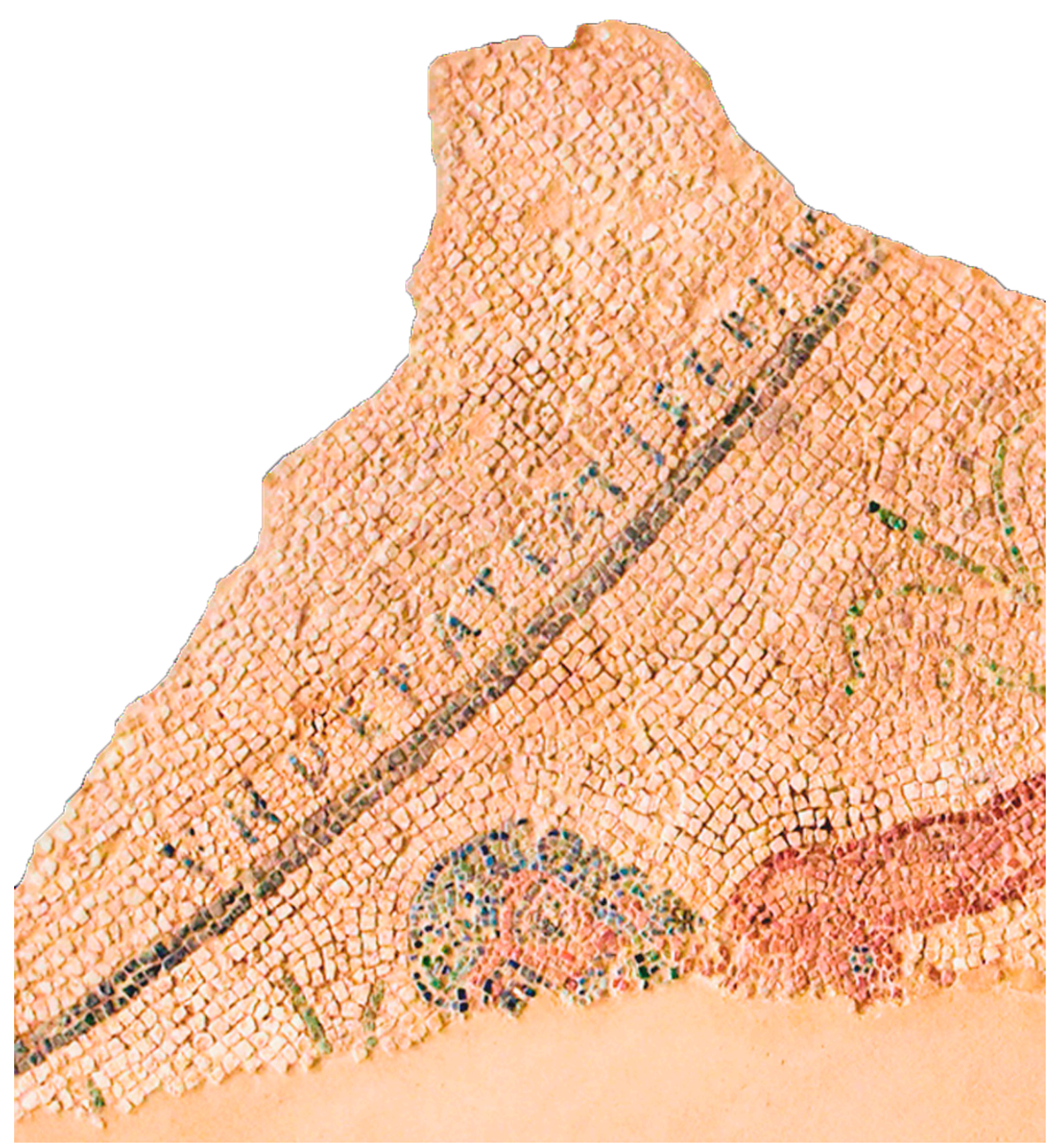

In the rest of the mosaic, the preserved fragments show remains of marine animals, so it is more than likely that nereids were represented riding on a fantastic sea-horses or on sea monsters (Vargas-Vázquez - Romero 2014: 145146); characters that would also be present in the exedras that open on the sides of the room, at least in one of them. This would be the previously mentioned exedra located on the west side, where the remains of what could have been the tail of another sea monster can be seen, allowing us to discern again the possibility of the representation of nereids (Vargas-Vázquez - Romero 2014: 148-152), all accompanied by an interesting marine fauna.

One of the most significant elements of the figurative decoration of this villa is the frequent allusion to water. This is repeated in the central space of the peristyle, where different representations of fish, dolphins and water birds can be seen (Vargas-Vázquez - Romero 2014: 156-159).

\section{Conclusions}

The study of Antequeran mosaics shows once again the richness of the Roman Baetica, which is clearly evident in the urban and rural environment. In the latter, the great Roman villae reveal wealth and splendour with the construction of large building complexes that make use of prestigious elements such as sculpture and mosaic.

As we have seen, most of the Roman mosaics in Antequera were found in villae. The mosaics found in the baths of Santa Maria suggest that they were used in
Figure 26

Mosaic of triclinium. Inscription. Fregment 3. Courtesy of Oficina Arqueológica de Antequera. 
urban areas. It is also noteworthy that mosaics, types of pavement preferred by the wealthiest layers of society, and were also used to pave public spaces.

Considering the entire Antequeran Mosaic ensemble and a comparison between the pavements of the different villae, and also between them and those preserved in the Baths of Santa Maria, one can postulate that there are no clear elements to define common features or connections between them. No relation can be seen in preference, nor fashion or tendencies within the same chronology; neither is it possible to delimit the activities of the same workshop geographically.

This lack of a clear reference occurs even considering that there are common elements that are generally found in Roman mosaics. The reason can mainly be that the mosaics of the villae do not coincide in the temporal frame. Moreover, the lack of a greater number of pavements limits the possibilities of establishing more precise comparisons.

In this sense, we must not forget that the number of pavements that still exist in Antequera are no more than a small sample of those that originally paved their domus and villae. From a chronological point of view, only the mosaics of the baths of Santa Maria would be in a time frame close to those of the Roman villa of Bobadilla. Nevertheless, apart from the detail of framing the figurative representation in a small central box, their stylistic differences are noticeable and evident.

Regarding the mosaics of the villa of La Estación and those of Caserío Silverio, these are also chronologically close to each other and show much more significant typological and stylistic differences.

Among all Antequeran mosaics, geometry is commonly the most prominent and used element, either as an individual adornment or as the dominant decoration, especially in the mosaics of the villa of La Estación. In that sense, its presence is also documented in one of the pavements of the Roman villa of Bobadilla and in another Roman villa at Caserío Silverio. The latter is surrounded by a broad field of opus figlinum.

Geometry is a perfect framework to present and to experience the main scenes or representations, figurative or of any other type. This is the model chosen for the mosaic of the Baths of Santa María, where the cube field encompasses a beautiful representation of Oceanus. It also occurs in the mosaic of the Roman villa of Bobadilla, in which the majestic representation of Priapus predominates. Both specimens are conceived as geometric fields that surround a single central emblem. Although similar, the other mosaic of Bobadilla, with the lost emblem, is of a different type. This can be understood since the main representation, which is now lost, was set inside a large box framed by borders; all this was accompanied by a secondary field of octagons.

Geometry, also conceived as a framework, is designed in more extensive sections and with a greater number of spaces reserved for figurative representations. Geometrical patterns occur in many mosaics, such as in the mosaic of the erotes figure of the villa of La Estación, in which the composition of scuta crosses dominates. Furthermore, it is part of the mosaic that paves the porches of the peristyle of the Roman villa of Caserío Silverio, in which the chosen design is straight and oblique squares. It can also be seen in the impluvium, where the main design is an octagon composition.

Nevertheless, the depiction of extensive figurative scenes in large spaces was the formula chosen in the villa of Caserío Silverio for the pavements of the 
triclinium and a sector of the impluvium mosaic.

The pavement of the apodyterium of the baths of Santa María contrasts with this type of mosaics because of the two emblems located inside a broad field of ceramic tesserae. Here, the geometric element is absent. This type of pavement in which a wide field of ceramic tesserae surrounds smaller mosaic surfaces is also identified, as we have already noted, in the Roman villa of Caserío Silverio, despite the chronological difference between the two sites. All in all, this shows that the model was used in the Baetica province for a long time.

The mosaic of the Roman villa of Carnicería de los Moros is unique in the Antequeran area. It presents a contour of ceramic tesserae in which a line of white tesserae intersected with equidistant knots is inserted, and a border decorated with a richly coloured three-strand braid. This braid is well executed and delimits an apparently non-compartmental inner field of yellow or ochre tesserae without decoration. These types of pavements, far from constituting a rarity, are documented in other places, such as in Ecija, the old Astigi. As in our case, they can also be seen decorating corridors and galleries in some pavements of Villa Adriana in Tivoli. Furthermore, this is found in other outstanding and emblematic spaces. It is assumed that beautiful and richly decorated carpets were placed on those pavements to embellish them.

Within the figurative representations of the Antequeran mosaics, mythology is by far the predominant theme, conceiving the scenes in an isolated way and with a simple representation, as we have already seen, like in the case of the emblems of Priapus and Oceanus. These scenes appear in several shared spaces that contain different parts of the same theme, which is the intention of the mosaic of the erotes of the villa de La Estación, and in the impluvium of the villa of Caserío Silverio. In the triclinium mosaics of the Roman villa of Caserío Silverio and in one of the sectors of the impluvium mosaic, a broader space reflects a much wider scene. It is likely that all the figurative mosaics of this villa had as a common feature the depiction of the mythology of waters. That was also a feature of the mosaics found in the Roman baths of Santa María9. Within the villa of Caserío Silverio, the inscription of the triclinium mosaic, aside from constituting a rarity within the mosaic ensemble in general, highlights the cultural concerns and taste of a rich and surely cultured dominus.

Finally, we can only point out that vegetation is not a particularly recurring element among the Antequeran mosaics, since it is used predominantly in a secondary way, as part of the decoration of borders, as isolated figures accompanying emblems or decorating the occasional geometric figure. However, inside the whole complex, the mosaic of the atriolum of the villa of La Estación stands out. Here, the rinceaus or scrolls of hedera that flow from the craters, covering the entire space, can be appreciated.

9 In other Antequeran and Baetican sites, is not usual to find figurative mosaics in the same building centred in one theme. 


\section{Bibliography - Kaynaklar}

Aguilar 1892

Atencia 1991

Atencia et al. 1990

Blázquez 2008

Brewster 1997

Caetano - Mourão 2012

Cisneros et al. 2016

Eraslan 2012

Eraslan 2015

Espinar et al. 2014

Espinar et al. 2016

Fernández - Romero 2007

Fernández et al. 2010

Foucher 1975

Gais 1978

Gómez 2014

López Monteagudo 2006

López Monteagudo 2010

López Monteagudo 2011

Mañas - Vargas-Vázquez 2007 I. Mañas Romero - S. Vargas-Vázquez, "Nuevos mosaicos hallados en Málaga: las villas de La Estación y de la Torre de Benagalbón”, Mainake 29, 315-338.

Mourão 2010

Montero 2012

Ostrowski 2012

Paulian 1979

Riñones 1987

A. Aguilar y Correa, "Mosaicos de Bobadilla", BacRHist 20, 100-105.

R. Atencia Páez, "Excavaciones de urgencia en las termas romanas de Santa María (Antequera, Málaga)", Actas de las IV Jornadas de Arqueología Andaluza, Jaén, 157-159.

R. Atencia Páez - M. Romero Pérez - I. Rueda Rodríguez, "Excavaciones de urgencia en las Termas Romanas de Santa María. Campaña de 1988”, AnArqAnd 1988, III, 220-226.

J. M. Blázquez Martínez, “Esculturas y mosaicos de Príapo en Hispania”, E. La Roca - P. León - C. Parisi (eds.), Le due patrie acquisite. Studi di archeologia dedicati a Walter Trillmich, Roma, 107-115.

H. Brewster, The River Gods of Greece: Myths and Mountain Waters in the Hellenic World, London.

M. T. Caetano - C. Mourão, "A "Portrait" of Book XII of the Æneid: the mosaic from the «House of the Medusa» (Portugal, Alter do Chão)”, M. Şahin (ed.), $11^{\text {th }}$ International Colloquium on Ancient Mosaics, Bursa, 205-224.

M. I. Cisneros García - M. Romero Pérez - S. Vargas-Vázquez, "Huerta del Ciprés”, R. Hidalgo Prieto (coord.), Las villas romanas de la Bética II, Catálogo, Sevilla, 453-457.

Ş. Eraslan, “Antik Dönem Sanatında Okeanos Figürleri”, Sanat Dergisi 22, 157-166.

Ş. Eraslan, "Iconographic differences of Oceanus in the mosaic art", G. Trovabene (a cura di), XII Colloquio AIEMA: Venezia, Verona, 195-200.

A. M. Espinar Cappa - M. I. Cisneros García - L. E. Fernández Rodríguez, "La fase romana del yacimiento arqueológico de la villa de Caserío Silverio-Mayorga”, A. M. Espinar Cappa - L. E. Fernández Rodríguez - M. Romero Pérez (coords.), La villa romana de Caserío Silverio, Antequera, 66-97.

A. M. Espinar Cappa - M. I. Cisneros García - M. Ferrando de la Lama - A. Arcas Barranquero - L. E. Fernández Rodríguez - M. Romero Pérez, “Caserío Silverio (Antequera, Málaga)”, R. Hidalgo Prieto (coord.), Las villas romanas de la Bética II, Catálogo, Sevilla, 423-430.

L. E. Fernández Rodríguez - M. Romero Pérez, "Las necrópolis en el entorno de Antikaria y Singilia Barba. Bases para su estudio sistemático", Mainake 29, 401-432.

L. E. Fernández Rodríguez - M. Romero Pérez - A. Arcas Barraquero, "El complejo alfarero romano del Arroyo Villalta. Bobadilla, Antequera (Málaga)”, Romula 9, 177-200.

L. Foucher, "Sur 1'iconographie du dieu Ocean", Caesarodunum 10, 48-52.

M. Gais, "Some problems of River-God Iconography", AJA 82, 3, 355-370.

J. Gómez Pallarès, "Virgilio musivo en Antequera”, M. I. Cisneros - L. E. Fernández - M. Romero (coord.), La villa romana de Caserío Silverio, Antequera, 168-178.

G. López Monteagudo, “Oceanus on the Roman Mosaic Pavements of Spain”, G. Wiplinger (ed.), Cura Aquarum in Ephesus: Proceedings of the $12^{\text {th }}$ International Conference on the History of Water Management and Hydraulic Engineering, Ephesus, Leuven, 485-491.

G. López Monteagudo, "Mosaicos", P. León (coord.), Arte Romano de la Bética: Mosaico. Pintura. Manufacturas, vol. 3, Sevilla, 17-186.

G. López Monteagudo, "La iconografía del dios Oceanos en los mosaicos hispano-romanos", V. Correia (ed.), $\mathrm{O}$ mosaico antigo nos centros e nas periferias: originalidades, influencias e identidades, Actas do X Colóquio internacional da AIEMA, Coimbra, 287-302.

C. Mourão, AVTEM NON SVNT RERVM NATVRA - Figurações heteromórficas em mosaicos hispanoromanos, Vols. I-II, tese de Doutoramento, Faculdade de Ciências Sociais e Humanas, Universidade Nova de Lisboa, Lisboa. (online: https://run.unl.pt/handle/10362/6268)

S. Montero, El emperador y los ríos: religión, ingeniería y política en el Imperio Romano, Madrid.

J. A. Ostrowski, Personifications of rivers in Greek and Roman art, Cracovia.

A. Paulian, "Le Dieu Océan en Espagne: un thème de l'art hispano-romain”, MelCasaVelazquez 15, 115-133.

A. Riñones Carranza, "Intervención de urgencia en el Ninfeo romano de Carnicería de los Moros (Antequera, Málaga), 1985”, AnArqAnd 1985 III, 251-256. 
Riñones 1989

Rodríguez 1987

Rodríguez 1988

Rodríguez 2011

Romero 1998

Romero 2001

Romero 2011

Romero 2011-2012

Romero et al. 2006

Romero et al. 2010
Romero 1992

A. Riñones Carranza, "El Ninfeo romano de Carnicería de los Moros”, Crónica del XIX Congreso Arqueológico Nacional, vol. 1, Zaragoza, 1081-1090.

P. Rodríguez Oliva, Mosaicos Romanos de Bobadilla (Málaga), Málaga.

P. Rodríguez Oliva, "Los mosaicos de la villa romana de Bobadilla (Málaga)”, BSAA 54, 137-169.

M. I. Rodríguez López, "Iconografía de océano en el Imperio Romano: el modelo metropolitano y sus interpretaciones provinciales", T. Nogales - I. Rodà (eds.), Roma y las provincias: modelo y difusión I, Roma, 541-549.

M. Romero Pérez, “Termas romanas en Antequera”, RAMadrid 129, 56-62.

M. Romero Pérez, "Algunas reflexiones sobre la producción de aceite en las villae de la comarca de Antequera", Mainake 19-20, 115-141.

M. Romero Pérez, "Algunas reflexiones sobre la producción de aceite en las villae de la comarca de Antequera”, Revista de Estudios Antequeranos 12, 278-279.

M. Romero Pérez "La villas romanas de la depresión de Antequera", M. Romero Pérez (ed.), El Efebo de Antequera, Antequera, 53-80.

M. Romero Pérez, "Producción oleícola durante la antigüedad en la depresión de Antequera: Estudios en el ager antikariensis y singiliensis", Anales de Prehistoria y Arqueología 27-28, 381-399.

M. Romero Pérez - I. Mañas Romero - S. Vargas-Vázquez, "Primeros resultados de las excavaciones realizadas en la Villa de La Estación (Antequera, Málaga)”, AespA 79, 239-258.

M. Romero Pérez - I. Mañas Romero - S. Vargas-Vázquez, "Excavaciones realizadas en la Villa de La Estación (Antequera, Málaga)”, AnArqAnd 2006, III, 3569-3590.

Romero - Vargas-Vázquez 2012 M. Romero Pérez - S. Vargas-Vázquez, "Mosaic workshop located in the Station Villa of Antequera, Málaga (Spain)", M. Şahin (ed.), $11^{\text {th }}$ International Colloquium on Ancient Mosaics, Bursa, 823-828.

Romero - Vargas-Vázquez 2016 M. Romero Pérez - S. Vargas-Vázquez, “La Estación (Antequera, Málaga)”, R. Hidalgo Prieto (coord.), Las villas romanas de la Bética II, Catálogo, Sevilla, 437-447.

Romero - Vargas-Vázquez 2017 M. Romero Pérez - S. Vargas-Vázquez, “La villa romana de Bobadilla”, Romula 16, 119-138.

Vargas-Vázquez 2016

S. Vargas-Vázquez, Diseños geométricos en los mosaicos del Conventus Astigitanus, Oxford.

Vargas-Vázquez 2018

S. Vargas-Vázquez “Cube Designs in Roman Baetica Mosaics”, JMR 11, 315-331.

Vargas-Vázquez - López Monteagudo 2016

S. Vargas-Vázquez - G. López Monteagudo, "La decoración musiva”, R. Hidalgo Prieto (coord.), Las villas romanas de la Bética I, Sevilla, 419-441.

Vargas-Vázquez-Romero 2014 S. Vargas-Vázquez - M. Romero Pérez, "Los mosaicos de la villa romana de Caserío Silverio", M. I. Cisneros García - L. E. Fernández Rodríguez - M. Romero Pérez (coord.), La villa romana de Caserío Silverio, Antequera, 138-167.

Vargas-Vázquez - Romero 2016 S. Vargas-Vázquez - M. Romero Pérez, “Carnicería de los Moros (Antequera, Málaga)”, R. Hidalgo Prieto (coord.), Las villas romanas de la Bética II, Catálogo, Sevilla, 418-422. 